\title{
CHAPTER 1: REASONABLE ROYALTIES
}

Thomas F. Cotter, John M. Golden, Oskar Liivak, Brian Love, Norman V. Siebrasse, Masabumi Suzuki, and David O. Taylor

Forthcoming in PATENT Remedies AND Complex PRoducts: Toward a Global Consensus* (Brad Biddle, Jorge L. Contreras, Brian J. Love, and Norman V. Siebrasse, eds., Cambridge University Press)

\section{Table of Contents}

I. Preliminary Matters

A. Empirical Literature

B. Theoretical Justifications

C. Principal approaches

II. Reformulating Georgia-Pacific

III. Incremental Value and Other Issues

A. Incremental Value

1. Overview

2. Complements

3. Patented Alternatives

B. Hypothetical Bargain

C. Dividing Incremental Value

D. Timing of Hypothetical Negotiation

\footnotetext{
* This project was made possible by a gift from Intel Corporation to the Center for Law, Science \& Innovation at the
} Sandra Day O’Connor College of Law at Arizona State University. 
E. Information Set $\quad 52$

F. Comparable Licenses $\quad 57$

1. Comparability 59

$\begin{array}{lll}2 . & \text { Circularity } & 61\end{array}$

$\begin{array}{ll}\text { 3. Dynamic Considerations } & 68\end{array}$

$\begin{array}{lll}\text { G. } & \text { Entire market value rule and smallest saleable unit } & 71\end{array}$

IV. Practical Considerations $\quad 79$

A. $\quad$ Expert Evidence and Daubert Gatekeeping in the United States 80

B. “Kickers” for Reasonable Royalties $\quad 81$

C. Calibrated Evidentiary Burdens or Royalty Measures 83

Abstract: This chapter (1) describes the current state of, and normative basis for, the law of reasonable royalties among the leading jurisdictions for patent infringement litigation, as well as the principal arguments for and against various practices relating to the calculation of reasonable royalties; and (2) for each of the major issues discussed, provides one or more recommendations. The chapter's principal recommendation is that, when applying a "bottom-up" approach to estimating reasonable royalties, courts should replace the Georgia-Pacific factors (and analogous factors used outside the United States) with a smaller list of considerations, specifically (1) calculating the incremental value of the invention and dividing it appropriately between the parties; (2) assessing market evidence, such as comparable licenses; and (3) where feasible and costjustified, using each of these first two considerations as a "check" on the accuracy of the other. 


\section{Preliminary Matters}

This Part will briefly describe (a) the extent to which reasonable royalties are awarded in the major jurisdictions for which descriptive statistics are available; (b) the principal theoretical justifications for awarding them; and (c) at a very general level, the principal methods for calculating them.

\section{A. Empirical Literature}

The empirical literature on reasonable royalties consists largely of descriptive statistics reporting median, average, or largest-ever patent damages awards for selected countries. These statistics provide insight into different jurisdictions' approaches and priorities related to awarding damages.

The most extensive literature on this subject pertains to the United States. According to a 2014 Lex Machina Patent Litigation Damages Report, for example, in 708 U.S. patent cases filed and terminated from 2000 to 2013, district courts awarded over $\$ 8$ billion in reasonable royalties, slightly less than $\$ 3$ billion in lost profits, and slightly more than $\$ 2$ billion incompensatory lump sum damages for which "the specific sub-type (reasonable royalties or lost profits) is not specified or the apportionment of the award between sub-types is not specified.” ${ }^{1}$ Lex Machina's list of median reasonable royalty, lost profit, and compensatory lump sum awards from 2000 to 2013

\footnotetext{
${ }^{1}$ Byrd et al. 2014, 1-4.
} 
indicates that reasonable royalty awards are more common than lost profits awards, but that in some years the median lost profit award exceeded the median reasonable royalty award. ${ }^{2}$ Lex Machina's Patent Litigation Year in Review 2016 reports median reasonable royalty damages in 2016 of $\$ 3,552,600$, based on 36 cases; median lost profits damages of $\$ 1,631,231$, based on 8 cases; and median "Other/Mixed Damages" of $\$ 67,785$, based on 18 cases. $^{3}$

PricewaterhouseCooperss (PwC) also publishes annual patent litigation reports. However, PwC reports median patent damages awards in the United States (excluding summary and default judgments) without separately accounting for lost profits and reasonable royalties. Interestingly, PwC’s reported median award for 1997-2016 (\$5.8 million in 2016 dollars) is considerably higher than the medians reported by Lex Machina for 2000-2015, most likely due to methodological differences between the two studies. ${ }^{4} \mathrm{PwC}$ also reports that in $80 \%$ of the cases in which courts awarded damages to practicing entities from 2007-2016 they awarded reasonable royalties. ${ }^{5}$ (Courts awarded lost profits in $40 \%$ of these cases; the percentages exceed 100\% because courts sometimes award lost profits on a portion of infringing sales and reasonable royalties on the remainder). Further, although nonpracticing entities (NPEs) had a lower win rate than practicing entities during the time period studied, the median award to NPEs that prevailed at trial from 2012-

\footnotetext{
${ }^{2}$ See id. at 6.

${ }^{3}$ See Howard \& Maples 2016, 32.

${ }^{4}$ For discussion of some differences in methodology, see Cotter \& Golden 2018, 15 n.65.

${ }^{5}$ We use the phrase "courts award” above even though in the majority of U.S. cases a jury awards damages. A judge ultimately must decide whether or not to enter final judgment in accordance with the verdict and the applicable rules of civil procedure.
} 
2016 was almost four times the median award to practicing entities (\$15.7 million versus $\$ 4.1$ million). ${ }^{6}$ Awards to NPEs almost always consist of reasonable royalties, rather than lost profits.

For other countries, less data is available, and the data that is available is generally less precise. Studies of Japanese damages awards indicate that reasonable royalty awards make up a plurality of all such awards ${ }^{7}$ but that the amounts awarded tend to be low by U.S. standards. For example, according to a 2014 study of all 68 cases from January 1, 1999, to March 5, 2013, in which Japanese courts awarded reasonable royalties, in only five cases did the award exceed $¥ 200,000,000$ (equal to about U.S. $\$ 1.7$ million). ${ }^{8}$ The royalty rate was $5 \%$ in $28 \%$ of cases, $3 \%$ in $22 \%$, and $10 \%$ in $16 \%$ (based on the value of the infringer's sales revenue from the infringing product). Like the PwC studies of U.S. damages, the reports of which we are aware on average or median damages awards in France do not distinguish between royalty and lost profits awards. ${ }^{9}$ In

\footnotetext{
${ }^{6}$ See Barry et al. 2017, 9-11, 16.

${ }^{7}$ See Matsunaka 2004.based on a review of all cases "published in the list of IPR related judgments on the Supreme Court website, in which the right holder claimed damages relating to IP . . . and for which judgment affirming all or part of the claim was rendered during the period from January 1, 1998, to December 31, 2003,” reporting that reasonable royalty awards made up the plurality in both patent (40 out of 79) and utility model (22 out of 42) cases from 1999-2003).
}

${ }^{8}$ Second Subcommittee of the Second Patent Committee 2014 (in Japanese); Cotter 2015 (discussing this article). See also Nakamura 2014, 407-10 (listing all Japanese patent damages judgments from January 1, 2003 to January 30, 2014); Yamaguchi 2016, 136 (reporting that there were thirteen first instance patent damages judgments in 2014, the top one being in the amount of $¥ 1,568,040,000$, equal to about $\$ 13.3$ million as of December 21, 2016).

${ }^{9}$ See, e.g., Dumont 2015 (reporting mean and median damages of $€ 323,270$ and $€ 60,000$, respectively, based on analysis of "483 patent infringement suits encompassing 673 patents" filed in the Tribunal de la grande instance de Paris from 2008 to 2013). But see République Française, Ministère du Redressement Productifs 2014, 58, 154-156 (in 
China, statutory damages predominate and awards of reasonable royalties are comparatively rare. ${ }^{10}$

\section{B. Theoretical Justifications}

As noted in the Introduction, for purposes of this project we take the substantive law of patents as a given, and do not advise courts to use the law of remedies to correct for perceived flaws in the substantive law. It follows from this premise that, in general, the law of patent damages should work to preserve the patent incentive, such as it is, by restoring the patent owner to the position it would have occupied, but for the infringement. Consistent with this rationale, courts and other observers often view reasonable royalty awards as a substitute for the royalty the patent owner would have earned, and that the infringer would have paid, absent the infringement. Commentators nevertheless sometimes express concern that such a standard threatens to encourage infringement (and to discourage ex ante negotiation), since it leaves the infringer no worse off for having infringed. This concern is particularly applicable if the royalty award is exactly the same as the royalty the patent owner would have negotiated, if the infringement was intentional, and if the infringer rationally could expect to avoid detection some nonzero percent of the time. ${ }^{11}$ In

a study comparing awards in France, Germany, and the United Kingdom from January 1, 2010 to August 1, 2013, and believed to cover approximately $25 \%$ of all decisions rendered during the applicable time periods, reporting inter alia that $36 \%$ of reasonable royalty awards in France and 50\% of such awards in Germany were for more than $€ 100,000)$. For discussion of other French studies, see Cotter \& Golden 2018, 17.

${ }^{10}$ See Cotter \& Golden 2018, 18. (citing literature).

11 This underdeterrence concern is likely to be less pronounced in cases in which the patent owner seeks an award of lost profits rather than reasonable royalties, because a patent owner presumably would seek lost profits only when it 
addition, the infringer may avoid some of the risks that a real-world licensee would incur ${ }^{12}$ though of course, if the infringer is sued, it may wind up incurring substantial attorney fees, which it otherwise could have avoided, to defend itself. ${ }^{13}$ To the extent that restorative damages risk underdeterring infringement, the law in the United States already ensures that royalty awards will not be exactly the same as what would have been negotiated, because the royalty awards must be

would have refused to license the infringer at all, due to the patent owner's or its exclusive licensee's superior efficiency in producing the patented product. See Blair \& Cotter 2005, 58. In addition, concerns that a reasonable royalty might discourage patent owners from commercializing their technology, by not taking the value of commercialization efforts into account, should be alleviated if the factfinder considers the impact such investments would have had on the bargain the patentee would have struck ex ante, including its timing and the relevant information set; the appropriate division of the value of the invention between the parties; and the selection of appropriate comparator licenses. See infra Parts III.A. through III.F.

${ }^{12}$ For example, in many countries a licensee may be able to avoid paying royalties once the patent is invalidated, but it would be unable to recover back the royalties it paid prior to invalidation. By contrast, an infringer who challenges validity can avoid paying royalties altogether if the patent is invalidated (and in some countries with bifurcated infringement and validity proceedings, the "infringer" may even be entitled to recover back any damages it paid prior to invalidation). In addition, an intentional infringer may be aware from the time it begins infringing that there is a market for the patented product—unlike a licensee, who at the time the license is concluded may face an uncertain demand for the product—and may avoid other disadvantages, such as upfront royalty payments or submitting to periodic inspections by the patentee.

${ }^{13}$ See AIPLA 2015, I-105-108 (reporting that the median cost of litigating a patent infringement suit with less than \$1 million at risk through to judgment is $\$ 600,000$; for a suit with between $\$ 1$ million and $\$ 10$ million at risk, $\$ 2$ million; for a suit with between $\$ 10$ million and \$25 million at risk, \$3.1 million; and for a suit with over \$25 million at risk, $\$ 5$ million). For estimates of the cost of litigating a patent infringement action in other countries, see generally Elmer \& Gramenopoulos 2016; Heath 2015. 
calculated based on an assumption that the patent in question is valid and infringed, whereas in actual negotiations the parties commonly reduce the royalty based on the possibility of invalidity and non-infringement. ${ }^{14}$ In addition, to address the risk of underdeterrence due to non-detection, policymakers could authorize courts to (1) grant injunctions, (2) award the disgorgement of the infringer's profits, (3) shift fees to the prevailing party, (4) impose criminal sanctions, or (5) award enhanced damages. Other chapters of this book discuss these alternatives in depth. However, as specifically discussed in Chapter 3, many countries decline to award enhanced or punitive damages on public policy grounds - though in some of these countries, courts occasionally award reasonable royalties above the "normal" rate to reflect the infringer's avoidance of risks that a good-faith licensee would have incurred. ${ }^{15}$

Alternatively, one could view reasonable royalties as a form of restitution, in the sense that the award forces the infringer to pay back the royalty it wrongfully withheld from the patentee. ${ }^{16}$ Whether the characterization of royalties as restorative or restitutionary makes any practical difference may depend on whether the focus is on awarding the royalty the parties would have negotiated absent the infringement, or the royalty the infringer should be required to pay in light of some normative criterion. The "hypothetical bargain” or "willing licensor-willing licensee” approach, as it is often applied in the United States, might seem to be an example of the former

\footnotetext{
${ }^{14}$ See generally Taylor 2014.

${ }^{15}$ For discussion, see, e.g., Cotter 2013a, 269-70 (discussing this possibility under French and German law). Although the theory is economically sound, courts and commentators in France and Germany have not universally embraced such awards due to their resemblance to disfavored enhanced or punitive damages.
}

${ }^{16}$ See Restatement (Third) of Restitution and Unjust Enrichment $§ 42$ cmt. a. 
approach, insofar as it attempts to construct the terms of the bargain the parties themselves would have negotiated prior to the date of infringement. But even that approach does not construct the exact bargain the parties would have made, because the hypothetical negotiation assumes the patent in question was valid and infringed, as discussed above. Without these assumptions, there would appear to be little difference between characterizing reasonable royalties as restorative or restitutionary. The royalty the court believes the patent owner would have earned absent the infringement is identical to the infringer's gain (i.e., the royalty it withheld, if not adjusted upward to reflect certainty as to validity and infringement). ${ }^{17}$ On the other hand, an approach that attempts to determine the royalty the infringer should be required to pay does not necessarily entail restoring the parties to the positions they actually would have occupied but for the infringement-though any such approach needs to specify just what the appropriate normative criterion is. Some recent scholarship recommends focusing more on the benefit the infringer actually derived from the use of the invention (as opposed to its expected benefits ex ante), so that the resulting award will more closely correlate with the invention's contribution to the art. As discussed in Parts II and III, one

\footnotetext{
${ }^{17}$ See Cotter 2013b. One drawback of an approach that attempts to construct the bargain the parties would have struck is that it does not provide much guidance in cases in which (1) no bargain would have been struck, because the patentee preferred exclusivity and would not have licensed the infringer at any rate the infringer would have accepted, but (2) the plaintiff cannot, or chooses not to, prove its own lost profits. It also does not provide much guidance on what to do when the parties' evidence is defective but the court is statutorily obligated to award some royalty anyway, as is arguably the case for example under 35 U.S.C. § 284. In such instances, reliance on industry standard rates or other nonspecific evidence may be the only available fallback.
}

Note also that when the infringer is required to give up the entire profit or cost saving it derived from the use of the patented invention, the remedy is more appropriately characterized as "disgorgement" or an "accounting of profits,” as opposed to a reasonable royalty. For further discussion, see Chapter 2. 
would then have to determine how to divide that benefit between the parties. In theory, the division could be based on what the parties likely would have negotiated ex ante, or on industry custom or other criteria. ${ }^{18}$ Other recent scholarship also suggests that a restitutionary approach to patent damages would provide courts with more flexibility to adjust the requisite level of proof based on factors such as the stakes involved and the extent to which the infringer was at fault. ${ }^{19}$

\section{Principal approaches}

Courts throughout the world often consider a range of factors in calculating reasonable

${ }^{18}$ See, e.g., Risch 2018 (arguing that reasonable royalties should reflect the value of the use of the patented invention to the infringer); Siebrasse \& Cotter 2016 (proposing that, consistent with the standard sometimes articulated by German courts, U.S. courts aspire to construct the bargain the parties would have negotiated ex ante with full knowledge of all relevant information that is made known ex post); Taylor 2014 (arguing that reasonable royalties should reflect the value of the use of the patented technology). Compare BGH v. 14.3.2000 - X ZR 115/98 (Ger.) (stating that "what is owed is what reasonable contracting parties would have agreed to, at the conclusion of a licensing agreement, if they had foreseen the future development and specifically the duration and amount of the use of the patent”), with General Tire \& Rubber Co. Ltd. v. Firestone Tyre \& Rubber Co. Ltd. (HL 1975, p.186-87) (UK) (in a case in which the trial court had awarded a royalty of one U.S. cent per pound of tire tread stock (T.T.S.), based on evidence that the infringer's use of the patented method reduced its costs by 1.8 old pence per pound of T.T.S., holding on appeal that a proper royalty would have been only 3/8 of a U.S. cent per pound of oil extended rubber (O.E.R.), based on the "going rate" the patentee had charged others for the use of the invention).

${ }^{19}$ See Golden \& Sandrik 2017. It is also conceivable that, if restitutionary awards are characterized as equitable in nature, there might not be a constitutional right to trial by jury on the amount of the award under U.S. law, though the point is highly debatable. See Cotter 2013b, 25-29. 
royalties. One approach often used in the United States, the U K, and some other countries is to construct the hypothetical bargain to which the court believes the parties would have agreed to avoid infringement. ${ }^{20}$ As discussed above, the hypothetical bargain approach may be viewed as either restorative or restitutionary. If the resulting royalty reflects what the parties actually would have negotiated, the patentee is rendered no worse off, and the infringer no better off, compared to the positions they would have occupied had they actually negotiated a license. As discussed in the following Parts, however, among the issues courts may need to address in constructing such a hypothetical bargain are (1) the timing of the bargain, (2) the knowledge the court should impute to the parties (including knowledge of validity and infringement of the relevant patent, as discussed above), and (3) the relevant factors that are probative of the terms of the bargain. Alternatively, as suggested above, an approach that focuses on dividing the actual gain to the infringer could still be cast as a hypothetical bargain, albeit one in which the parties agree ex ante on how to divide the benefit the infringer actually derives ex post. ${ }^{21}$ This approach would be less concerned, than the more common Georgia-Pacific approach, with trying to accurately construct the terms the parties themselves actually would have negotiated ex ante.

Another option under U.S. law is the so-called "analytical approach,” which "focuses on the infringer's projections of profit for the infringing product.”22 The leading case is TWM Mfg.

\footnotetext{
${ }^{20}$ See, e.g., Georgia-Pacific Corp. v. U.S. Plywood Corp. (S.D.N.Y. 1970, p.1120) (U.S.); General Tire \& Rubber Co. Ltd. v. Firestone Tyre \& Rubber Co. Ltd. (HL 1975, p.178-79 (opinion of Lord Wilberforce), 188-89 (opinion of Lord Salmon)) (UK).

${ }^{21}$ See Siebrasse \& Cotter 2016.

${ }^{22}$ Lucent Techs., Inc. v. Gateway, Inc. (Fed. Cir. 2009, p.1324) (U.S.).
} 
Co. v. Dura Corp. ${ }^{23}$ in which the Federal Circuit approved a damages award that involved subtracting “the infringer's usual or acceptable net profit from its anticipated net profit realized from sales of infringing devices.” Although courts sometimes permit the patentee who employs the analytical approach to use the infringer's actual profits as a proxy for expected profits, ${ }^{24}$ the approach does not appear to be used very frequently. Critiques of the analytical approach argue, among other things, that the method is indistinguishable from disgorgement; that the concept of a “usual or acceptable net profit” is not very precise; that the approach does not account for various other factors that can explain a divergence from the normal rate of return, including the presence of other product features, or for the fact that different products can have different profit margins; and that the approach can unfairly penalize an infringer who has a higher profit rate due to efficiencies in production. ${ }^{25}$

Where an established royalty rate exists, courts sometimes have used that rate rather than

${ }^{23}$ TWM Mfg. Co., Inc. v. Dura Corp. (Fed. Cir. 1986, p.899) (U.S.). The infringer's expected profit from the sales of products incorporating the patented technology also was an important factor in the Second Circuit's modification of the royalty awarded in Georgia Pacific. See Georgia-Pacific Corp. v. U.S. Plywood Corp. (2d Cir. 1971, p.289-99) (U.S.). For further discussion of the analytical approach, see Skenyon et al. 2016, § 3.8; Cox 2017; Gooding 2012; Pedigo 2017; Rooklidge 2014.

${ }^{24}$ See Pedigo 2017.

${ }^{25}$ See Cox 2017 (arguing that the analytical approach is economically deficient, for reasons stated in the text above); Gooding 2012, 7 (critiquing the analytical approach on the ground, inter alia, that it "assumes that every penny of additional profit (above the infringer's 'usual' or 'acceptable' profit) is attributable solely to the patented invention. It therefore makes no attempt to account for the importance of the infringed technology in generating those incremental profits and does not reflect 'the invention's contribution to the infringing product or service'”) (quoting Uniloc USA, Inc. v. Microsoft Corp. (Fed. Cir. 2011, p.1313) (U.S.); Rooklidge 2014. 
endeavoring to construct a hypothetical bargain or an appropriate division of the profits projected or earned from the use of the invention. ${ }^{26}$ Where no such established rate exists, courts nevertheless frequently turn to comparable license rates as an aid in constructing the hypothetical bargain. In some countries, courts also make extensive use of what are believed to be industry standard rates for various technologies. For example, in Japan courts often start with the standard royalty rate for a given technological field, as reported in publications of the Japanese Institute of Inventors and Innovation (Hatsumei Kyokai), and then adjust the rate up or down based on factors such as "the technical or economical value and importance of the invention,” the plaintiff's own high profit margin, the contribution of the invention to the infringer's profitability or to the value of the end product, the existence of alternatives, and the infringer's sales volume. ${ }^{27}$

A fourth possibility would be to employ some sort of "top-down" approach as in In re Innovatio IP Ventures, LLC Patent Litigation, ${ }^{28}$ whereby the court identifies an appropriate royalty

\footnotetext{
${ }^{26}$ See, e.g., Rude v. Westcott (U.S. 1889, p.164-65) (U.S.) (stating that, to qualify as an established royalty, the rate "must be paid or secured before the infringement complained of," "must be paid by such a number of persons as to indicate a general acquiescence in its reasonableness by those who have occasion to use the invention," "must be uniform at the places where the licenses are issued," and should not be paid in settlement of another infringement claim). For discussion, see Cotter 2013a, 108.

${ }^{27}$ See Second Subcommittee of the Second Patent Committee 2014 (in Japanese); Cotter 2015. See, e.g., Fulta Elec. Machinery Co. v. Watanabe Kikai Kogyo K. K. (IP High Ct. 2015) (Japan).

${ }^{28}$ In re Innovatio IP Ventures, LLC Patent Litigation (N.D. Ill. 2013) (U.S.). See also Samsung Elecs. Co. v. Apple Japan LLC (IP High Ct. 2014, p.132-38) (Japan) (applying a form of top-down analysis); Unwired Planet Int'l Ltd. v. Huawei Techs. Co. (Pat 2017, ๆf 475-80) (UK) (applying a top-down approach as a cross-check on the FRAND royalty derived from analysis of comparables).
} 
base; decides how much of the revenue attributable to the base should be payable as aggregate royalties; and then determines what portion of those aggregate royalties should accrue to the patents in suit, based on their relative importance. Some form of "top-down" approach may be used in cases involving complex products, but the accuracy of the approach in estimating the value of the patents in suit depends upon obtaining a considerable amount of arguably difficult-to-obtain information. ${ }^{29}$ This approach is discussed further in Chapter 5 on the effect of FRAND commitments on patent remedies.

\section{Reformulating Georgia-Pacific}

Judicial systems throughout the world often permit the finder of fact to consider a range of factors of arguable relevance to the calculation of reasonable royalties. In the United States, for example, damages expert witnesses frequently base their opinions on the fifteen factors first compiled in Georgia-Pacific Co. v. U.S. Plywood Co. (set forth below) ${ }^{30}$ Courts in other countries,

${ }^{29}$ See Cotter 2018, 206-211.

30

1. The royalties received by the patentee for the licensing of the patent in suit, proving or tending to prove an established royalty.

2. The rates paid by the licensee for the use of other patents comparable to the patent in suit.

3. The nature and scope of the license, as exclusive or non-exclusive; or as restricted or nonrestricted in terms of territory or with respect to whom the manufactured product may be sold.

4. The licensor's established policy and marketing program to maintain his patent monopoly by not licensing others to use the invention or by granting licenses under special conditions designed to 
preserve that monopoly.

5. The commercial relationship between the licensor and licensee, such as, whether they are competitors in the same territory in the same line of business; or whether they are inventor and promoter.

6. The effect of selling the patented specialty in promoting sales of other products of the licensee; the existing value of the invention to the licensor as a generator or sales of his non-patented items; and the extent of such derivative or convoyed sales.

7. The duration of the patent and the term of the license.

8. The established profitability of the product made under the patent; its commercial success; and its current popularity.

9. The utility and advantages of the patent property over the old modes or devices, if any, that had been used for working out similar results.

10. The nature of the patented invention; the character of the commercial embodiment of it as owned and produced by the licensor; and the benefits to those who have used the invention.

11. The extent to which the infringer has made use of the invention; and any evidence probative of the value of that use.

12. The portion of the profit or of the selling price that may be customary in the particular business or in comparable businesses to allow for the use of the invention or analogous inventions.

13. The portion of the realizable profit that should be credited to the invention as distinguished from non-patented elements, the manufacturing process, business risks, or significant features or improvements added by the infringer.

14. The opinion testimony of qualified experts.

15. The amount that a licensor (such as the patentee) and a licensee (such as the infringer) would 
have agreed upon (at the time the infringement began) if both had been reasonably and voluntarily trying to reach an agreement; that is, the amount which a prudent licensee-who desired, as a business proposition, to obtain a license to manufacture and sell a particular article embodying the patented invention—would have been willing to pay as a royalty and yet be able to make a reasonable profit and which amount would have been acceptable by a prudent patentee who was willing to grant a license.

Georgia-Pacific Corp. v. U.S. Plywood Corp. (S.D.N.Y. 1970, p.1120) (U.S.). Notice that the fifteenth GeorgiaPacific factor is the hypothetical bargain discussed above in Part II. On one view, the fourteen preceding factors are best viewed as aids in determining the fifteenth. See Durie \& Lemley 2010, 643. 
including Canada, ${ }^{31}$ Germany, ${ }^{32}$ and Japan, ${ }^{33}$ sometimes look to a similar range of factors.

Critics nevertheless have noted several potential problems with the Georgia-Pacific framework. First, depending on the facts of the case, some of the Georgia-Pacific factors may

${ }^{31}$ See AlliedSignal Inc. v. DuPont Canada Inc. (Fed. Ct. 1998, \ 209) (Can.) (listing as potentially relevant factors in constructing a hypothetical license: (1) whether the patentee would have need to transfer technology to the implementer; (2) differences in the parties’ practice of the invention; (3) whether the patentee would have agreed to an exclusive or nonexclusive license; (4) the territory covered by the license; (5) the term of the license; (6) whether there were available competing technologies; (7) whether the patentee and the implementer are competitors; (8) the demand for the infringing product; (9) the risk that the product would not sell; (10) the novelty of the invention; (11) the compensation needed for research and development costs; (12) whether the invention would result in increased revenues accruing to the licensee; and (13) whether the patentee has the capacity to meet market demand itself). See also Jay-Lor Int'l Inc. v. Penta Farm Sys. Ltd. (Fed. Ct. 2007, ๆ 147, 160-73) (Can.) (approving the use of these factors).

32 See Cotter 2013a, 268 (stating that German courts may take into account a range of factors, including the existence of non-infringing alternatives; "the terms of comparable licenses; the significance of the invention as suggested by the defendant's profit expectations; whether the use interferes with the patentee's monopoly position (Monopolstellung); the increase in value brought about by the use of the patented invention, including revenue from other goods that are sold and used together with it; and whether the revenue derived from the infringement is attributable in part to the infringer’s (or third parties’) technology.”).

${ }^{33}$ See id. at 321-22 (stating that Japanese courts often use as a starting point the standard rate for a given technological field as reported by the Japanese Institute of Inventors and Innovation (Hatsumei Kyokai), as well as "a variety of additional factors similar to those used in the United States and Canada, including the scope and significance of the patent and the benefits the defendant derives from its use.”); Second Subcommittee of the Second Patent Committee 2014 (article, in Japanese, discussing the factors that explain the royalty rates awarded by Japanese courts); Cotter 2015 (discussing the preceding article). 
simply be irrelevant, ${ }^{34}$ thus potentially distracting the trier of fact from focusing on the economically relevant considerations. ${ }^{35}$ Second, the framework offers little or no guidance to either the trier of fact or the judge on how to weigh or prioritize the factors. ${ }^{36}$ Third, and following from the first two points, it is sometimes said that a clever expert can manipulate the factors in support of virtually any award. ${ }^{37}$ As a consequence, it can be very difficult for the parties to predict

${ }^{34}$ See Ericsson, Inc. v. D-Link Sys. (Fed. Cir. 2014, p.1231, 1235) (U.S.) (vacating a damages judgment where the jury was instructed, among other things, on factors that were irrelevant to the facts of the case); Durie \& Lemley 2010, 628 (stating that Georgia-Pacific "overloads the jury with factors to consider that may be irrelevant, overlapping, or even contradictory”).

${ }^{35}$ See Contreras \& Gilbert 2015, 1499 (stating that "the Georgia-Pacific fifteen-factor analysis muddied the water substantially in 1970, allowing litigants and courts to focus on any number of confounding factors that distracted from the core inquiry regarding the value of the patented technology”); Durie \& Lemley 2010, 628.

${ }^{36}$ See Durie \& Lemley 2010, 631 (stating that “a non-exclusive fifteen-factor test that requires balancing and consideration of the interactions between the factors is likely to give little or no practical guidance to a jury"); Patent Reform Act of 2009: Hearing on H.R. 1260 (H. Comm. on the Judiciary 2009, p.75) (prepared statement of Professor John R. Thomas, Georgetown University Law Center) (stating that "the Georgia-Pacific factors are difficult to apply consistently" because the case "offers no recipe--that is to say, no principles for deciding whether one of the seemingly randomly ordered elements should be weighed more heavily than another in a given determination") (quoted in Seaman 2010, 1703-04); Schlicher 2009, 22 (stating that "juries are not given useful guidance on how to apply the socalled Georgia-Pacific factors”).

${ }^{37}$ See Cotter 2018, 193 (stating that "unless the judge exerts very tight control over the presentation of evidence, a clever expert could manipulate the factors to find support for virtually any damages amount”); Durie \& Lemley 2010, 632 (stating that "[t]he breadth of the available factors also means that it is difficult to exclude evidence or expert testimony espousing virtually any theory of reasonable royalty damages, no matter how outlandish," and that because "Georgia-Pacific provides little guidance as to which factors must be accorded the most weight in any given case, the 
how the trier of fact will apply the factors, and for a reviewing court to detect errors in their application. ${ }^{38}$ In combination, these problems threaten not only to reduce accuracy and increase costs, but also to make settlement more difficult and to place the more risk-averse party at a disadvantage. $^{39}$

In response to these problems, some recent scholarship and other initiatives advocate restructuring the analysis to focus on a smaller number of economically relevant factors. Most prominent, perhaps, are the Federal Circuit Bar Association’s Model Patent Jury Instructions,

expert's ultimate conclusion, no matter how extreme, can usually be justified by at least some combination of them”).

${ }^{38}$ See Durie \& Lemley 2010, 628, 632 (stating that "because the jury’s finding is the result of such a complex, multifactor test, it is as a practical matter almost entirely immune from scrutiny by either district or appellate judges facing a deferential standard of review," and that "the fifteen-factor test makes it extremely difficult for judges to review a jury damage award for substantial evidence, either on judgment as a matter of law (JMOL) or on appeal”); The Evolving IP Marketplace (Fed. Trade Comm’n 2009, p.15) (testimony of Professor Paul M. Janicke, University of Houston Law Center) (stating that Georgia-Pacific leads to "erratic results" because the test is like a "grab bag” where "the judge throws the grab bag with all the factors to the jury and says, 'Do what you think is right'”) (quoted in Seaman 2010, 1704); Seaman 2010, 1665, 1703 (stating that "the so-called Georgia-Pacific test . . . has become increasingly difficult for juries to apply in lengthy and complex patent trials, resulting in unpredictable damage awards," and that "Georgia-Pacific's absence of guidance for balancing the various factors contributes to a lack of certainty and predictability in reasonable royalty awards"); Taylor 2014, 151-52 (“No doubt one contributing factor to inaccuracy, uncertainty, and unpredictability regarding reasonable royalties is the relatively unbounded expert testimony and evidence allowed by the Georgia-Pacific factors and the hypothetical negotiation construct”).

${ }^{39}$ See Cotter 2018, 168 (stating that "the greater the range of possible outcomes (that is, the greater the variance around the expected mean), the smaller the probability that the parties will settle their dispute (thus raising administrative costs), and the greater the likelihood that the more risk-averse party will be willing to settle on unfavorable terms”). 
which propose that U.S. courts instruct juries to "consider all the facts known and available to the parties at the time the infringement began," but that "[s]ome of the kinds of factors that you may consider in making your determination are: (1) The value that the claimed invention contributes to the accused product. (2) The value that factors other than the claimed invention contribute to [the accused product]. (3) Comparable license agreements, such as those covering the use of the claimed invention or similar technology." ${ }^{40}$ In a similar vein, Durie and Lemley argue that the Georgia-Pacific factors largely "boil down to three fundamental questions: (1) what is the marginal contribution of the patented invention over the prior art?; (2) how many other inputs were necessary to achieve that contribution, and what is their relative value?; and (3) is there some concrete evidence suggesting that the market has chosen a number different than the calculus that results from (1) and (2)?”41 Jarosz and Chapman also have advocated a three-step framework, focusing on the incremental value of the invention over alternatives, comparable licenses, and design-around costs. ${ }^{42}$ In addition, Chien, Cotter, and Posner argue in a forthcoming book that courts should focus on comparing the benefits the infringer expected to derive or actually derived from the use of the patented invention against the benefits it would have derived from the use of the best non-infringing alternative. ${ }^{43}$

\footnotetext{
${ }^{40}$ FCBA 2016.In a recent article, Contreras and Eixenberger advocate the uniform adoption of the Federal Circuit Bar Association’s proposed jury instructions. See Contreras \& Eixenberger 2016.

${ }^{41}$ Durie \& Lemley 2010, 629.

${ }^{42}$ See Jarosz \& Chapman 2013.

${ }^{43}$ Chien et al. (forthcoming). See also Seaman 2010, 1667, 1711-26 (arguing that "the accused infringer's expected costs of adopting an acceptable non-infringing substitute" should serve as a ceiling on the amount of the reasonable
} 
Following from the above, our principal recommendation is that, when applying a "bottom-up"44 approach to estimating reasonable royalties, courts should replace the GeorgiaPacific factors (and analogous factors used outside the United States for calculating reasonable royalties) with a smaller list of considerations. More specifically, courts should collapse the Georgia-Pacific factors into the following three steps. (We defend each of the individual parts of this recommendation in detail in Part III below.)

\section{Calculate the incremental value of the invention and divide it appropriately between the} parties. A license for the use $\mathrm{u}^{45}$ of a patented technology typically requires the licensee to

royalty).

${ }^{44}$ This chapter uses the term "bottom-up" to refer to approaches in which the royalties due to patent holders in separate cases are for the most part determined independently of one another. As discussed supra note 28 and accompanying text, as an alternative to such an approach courts sometimes may employ a "top-down" approach, in which they first determine the aggregate royalty burden for a specific product or standard and then apportion that burden among the patents reading on that product or standard (see TCL Commc'ns Tech. Holdings, Ltd. v. Telefonaktiebolaget LM Ericsson (C.D. Cal. 2017) (U.S.); Unwired Planet Int'l Ltd. v. Huawei Techs. Co. (Pat 2017) (UK); Samsung Elecs. Co. v. Apple Japan LLC (IP High Ct. 2014) (Japan)). Although top-down approaches may help to reduce risks of holdup and royalty stacking, they may lend themselves more to cases involving patents declared essential to the practice of standards embodying a discrete set of technologies. Outside that context, the evidence needed to employ a top-down approach may be more difficult to obtain, given the lack of both a finite set of declared patents and a defined set of technological features for which royalties are due. Given this chapter's emphasis on complex products generally, therefore, its focus will be on improvements to the bottom-up approach, though in the end the decision whether to apply a bottom-up or top-down approach in FRAND or other complex product cases ultimately may depend on the availability and quality of the evidence before the court.

${ }^{45}$ As a shorthand, we employ the word "use," as in "use of the invention over alternatives,” though strictly speaking 
share with the licensor some portion of the incremental value the licensee derives or expects to derive from the use of that technology. To ensure that a reasonable royalty for the unauthorized use of a patented technology accurately reflects this incremental value, ideally a court would (1) estimate the difference between the value the infringer derived from the use of the patented invention (as distinct from the value contributed by other features of the infringing end product), and the value the infringer would have derived by using the next-best available non-infringing alternative instead; (2) divide that differential value between the patent owner and the infringer; and (3) as an aid in carrying out this division, consider any relevant evidence, including possibly the use of a rebuttable presumption that the parties would have agreed, ex ante, to an even (50/50) split.

2. Assess market evidence. In negotiating licenses for the use of patented technologies, parties often consider the rates and other terms disclosed in relevant comparable licenses (or, where applicable, the rates charged by relevant patent pools or disclosed in publications of industry standard rates). Courts also should consider such evidence for purposes of calculating reasonable royalties for the unauthorized use of patented technologies, albeit subject to appropriate adjustments and with due appreciation for the potential limitations of such evidence as discussed in Part III.F.

3. Comparison. When it is feasible and cost-justified, courts should carry out both steps described above—each one acting as a "check" on the accuracy of the other-and then

the infringer's conduct at issue could consist of any selection or combination of the specific activities, such as manufacturing, use, or importation, that can constitute infringement. 
attempt to reconcile or adjust the results, as the evidence warrants. That said, one can expect only that courts do the best they can with the evidence available to them. Thus, when the evidence necessary to carry out step 2 is available but the evidence necessary to carry out step 1 is not ${ }^{46}$ —as will likely often be the case in litigation involving complex productscourts may need to rely exclusively on market evidence. (The converse will be true when the available evidence relates only to step 1, not 2.) Furthermore, as discussed in greater detail in Chapter 5 on the effect of FRAND commitments on patent royalties, in appropriate cases courts also may consider applying a "top-down" approach either as direct evidence or as a check on the value derived from the use of comparables and other market evidence.

Explanation. As discussed in Part III.A below, economists generally accept "incremental value" - that is, the difference between the value derived from the patented invention over the next-best available non-infringing alternative-as an accurate measure of the value of patented technology.$^{47}$ By necessity, such an inquiry also requires the trier of fact to apportion the value attributable to the patented invention as opposed to other features of the infringer's product,

\footnotetext{
${ }^{46}$ See Unwired Planet Int’l Ltd. v. Huawei Techs. Co. (Pat 2017, ๆ 182) (UK) (stating that “There was ample evidence before me that ... parties negotiating SEP licences in fact use methods which are based on patent counting. That is evidence which supports a finding that a FRAND approach to assessing a royalty rate is to engage in some kind of patent counting. Indeed when one thinks about it some sort of patent counting is the only practical approach at least for a portfolio of any size. Trying to evaluate the importance of individual inventions becomes disproportionate very quickly.”).

${ }^{47}$ As is also discussed above, however, there are legitimate debates over whether the focus should be on actual or only expected advantages, and on how to proceed when the next-best alternative is itself patented.
} 
assuming that the non-infringing alternative end product sold by the infringer would have retained those other features. ${ }^{48}$ The first part of step 1 above therefore combines Georgia-Pacific factors 8, 9, 10 , and 13 into one overarching concept. ${ }^{49}$ Step 1 presumably will be easier to accomplish, however, when the infringing product embodies relatively few patented features. We defend our recommendation regarding the division of incremental value in Part III.C below.

Step 2 recommends that courts also make appropriate use of comparables and other market evidence of how actors in the real world value the technology in suit. To be sure, courts and commentators have identified numerous potential pitfalls in the use of comparables, which we discuss in greater detail in Part III.F below. These theoretical problems notwithstanding, however, we do not advocate forgoing the use of comparables (nor do we see that as a likely development, in any event), but rather emphasize the need for careful judgment in applying them. Moreover, at least in some cases a patent pool rate or other comparable may have a very high probative value,

${ }^{48}$ The simplest example would be one in which the infringer has sold both comparable products, one containing the patented feature and one without that feature, under similar market conditions, such that it is possible to infer the incremental benefit conferred by the patent. See, e.g., Grain Processing Corp. v. Am. Maize-Prods. Co. (Fed. Cir. 1999) (U.S.); Carson et al. v. American Smelting \& Refining Co. (W.D. Wash. 1928) (U.S.). To the extent the patented invention is complementary to other features of the infringer's product, however, as it often will be in complex products cases, apportionment becomes more complicated. See infra Part III.A (discussing a hypothetical in which the patented invention provides $20 \%$ longer battery life to a smartphone).

${ }^{49}$ See Cotter 2018, 192 n.133 (stating that among the most important Georgia-Pacific factors are 'factors 8 through 10 , all of which relate to the value of the patented technology, in terms of its effect on the implementer's profit or cost, in comparison with alternatives," and "factor 13, "the portion of the realizable profit that should be credited to the invention as distinguished from non-patented elements, the manufacturing process, business risks, or significant features or improvements added by the infringer'”). 
though that rate may need to be adjusted (for example, to account for the reasons why the patentee did not join the pool). ${ }^{50}$

Step 3 recommends that, where feasible, courts apply both Step 1 and Step 2, and then compare the results. To the extent the numbers generated by each step diverge, the court will then have to decide how best to reconcile them based on all of the relevant facts and circumstances. For example, a court may be more confident in the result generated by Step 1 when the end product embodies only a small number of patents or when there are few if any licenses that are closely comparable. By contrast, Step 2 may seem more probative when the product's complexity makes it difficult to distinguish the value contributed by a single patent over the next-best alternative. (On the other hand, even in complex products cases it sometimes may be possible to estimate the value of a specific patented feature relative to other features, through the use of conjoint or discrete choice analysis, testimony from technical experts, or application of some form of "top-down" approach as discussed in the FRAND chapter.) $)^{51}$ Further, in cases (1) involving relatively small stakes, or (2) arising in countries that impose substantial limits on pretrial discovery or the use of expert witnesses, or (3) in which the parties’ evidence on damages is inadmissible or incompetent, the best practice may be to consider comparables, industry standard rates, or other such market evidence, despite its potential drawbacks, rather than to award zero damages or rely on other, even more speculative, evidence of the value of the technology over alternatives.

\footnotetext{
50 See, e.g., Microsoft Corp. v. Motorola, Inc. (W.D. Wash. 2013) (U.S.).

${ }^{51}$ For discussion of the use of conjoint and discrete choice analysis in litigation, see, e.g., Platt \& Chen 2013; Sidak \& Skog 2016; Verma et al. 2002 (providing an accessible discussion of discrete-choice analysis).
} 


\section{Incremental Value and Other Issues}

In this Part, we present the analysis underlying our principal recommendation as described in Part II. We also present our recommendations relating to various issues that may arise either in the application of our principal recommendation or in the event courts continue to employ a multifactor, Georgia-Pacific-like approach to reasonable royalties.

\section{A. Incremental Value}

\section{Overview}

We perceive a widespread consensus among innovation economists and lawyers that the social value of a technology is its incremental value over the next-best alternative, and that the economic value of a patented technology to an implementer is the (actual or expected) profit or cost saving the implementer derives from the use of the patented technology over the next-best available non-infringing alternative. ${ }^{52}$ We therefore recommend that policymakers adopt, subject

\footnotetext{
52 See, e.g. Swanson \& Baumol 2005, 10-11; Farrell et al. 2007, 610-11; Elhauge 2008, 541; Denicolò et al. 2008, 577-78; Layne-Farrar et al. 2009, 448; Shapiro 2010, 286; Gilbert 2011, 864; Camesasca et al. 2013, 304; Cotter 2013a, 128; Carlton \& Shampine 2013, 536, 545; Jarosz \& Chapman 2013, 812; Taylor 2014, 95-97; Cotter 2014a, 357; Sedona Conference 2014, 23-24; Contreras \& Gilbert 2015, 1467-69, 1499-1500; Siebrasse \& Cotter 2017a; Lee \& Melamed 2016, 411-12; Epstein \& Marcus 2003, 557-58. See also Taylor 2014, 91-97 (contrasting the value of the technology with the value of patent rights, where the latter might include for example the ability to use an injunction to extract holdup value.)
} 
to the systemic considerations noted in the Introduction, the guiding principle that the royalties awarded in litigation should be commensurate with the value of the patented technology as so defined. ${ }^{53}$ We also recognize, however, that there are substantial difficulties, both practical and conceptual, in assessing that value-particularly in the case of complex products, where the patented technology contributes only a small part to the overall value of the product. In those contexts, a patented feature might be the deciding factor for a few purchasers, and it might increase the value to others, but for most purchasers it is likely to be one of a host of factors that shift buying preferences as a whole. We discuss the conceptual difficulties below.

\section{Complements}

The first conceptual difficulty involves complementarity between the infringing technology and other patented technologies that are also implemented in the same product. The problem is illustrated most clearly in a case in which two versions of a complex product are sold, with no difference between the two except that one version embodies the patented technology while the other does not. ${ }^{54}$ It may seem that this is a case in which it is easy to determine the incremental value of the patented technology; it would seem to be simply the difference between the two prices. However, this is not correct if, as is commonly the case, the patented technology

\footnotetext{
${ }^{53}$ Our recommendation that royalties should be "commensurate with" the value of the technology, however, does not amount to a recommendation that courts should aspire to award patentees the entire social value of their inventions. For discussion, see, e.g., Frischmann \& Lemley 2007; Golden 2010, 529-39; Lemley 2005, 1036-37; Taylor 2014, $138-41$.

${ }^{54}$ See Samsung Elecs. Co. v. Apple Japan LLC (IP High Ct. 2014, p.134) (Japan)
} 
depends on other patented technology. For example, suppose the patented invention provides for $20 \%$ longer battery life in a smartphone, and a smartphone with the longer battery life sells for $\$ 50$ more than the phone would with the shorter battery life it would otherwise have. The incremental value of the patented invention would appear to be $\$ 50$. But the price consumers are willing to pay for the phone depends on its patented wireless technology, and without that wireless technology the phone would be worthless, no matter how long the battery life. In that case, the $\$ 50$ price difference is only partially attributable to battery technology, because it is also partially attributable to the wireless technology. ${ }^{55}$ Put another way, the patentee holding the wireless technology might reasonably demand a higher royalty for the phone with the battery-extending technology than for the base phone, leaving only some part of the $\$ 50$ to be split between the battery patentee and the phone vendor. Whether the wireless patentee actually demands a higher royalty in such a case is a different question - though it is not unlikely that it would do so. It is common for patentees, particularly those with basic technology patents, to charge an ad valorem royalty on the product price, with the result that the wireless royalty would be higher for the more expensive phone.

\section{Patented Alternatives}

A second conceptual difficulty arises from the proposition that the value of the invention is its value over the best non-infringing alternative. This proposition is uncontroversial so long as the alternative is unpatented, but its application is not so clear if the alternative is patented. It is not at all uncommon that the best substitutes for a patented technology are also patented, as several

\footnotetext{
${ }^{55}$ In economic theory the independent value of the complementary technology is given by the Shapley value. See Siebrasse \& Cotter 2017a. However, it will rarely be possible to compute Shapley pricing directly.
} 
inventors devise different solutions to the same problem. ${ }^{56}$ The problem is illustrated most clearly when the inventions are near perfect substitutes, ${ }^{57}$ and it is particularly salient in the context of standard-essential patents (SEPs), where it is often the case that multiple alternative patented technologies competed for inclusion in the standard.

One possibility is that in such a case the value of the patented invention is zero, on the view that the infringing user in the hypothetical negotiation should be imagined to play one patentee off against another until the patentee is haggled down to its minimum willingness to accept. ${ }^{58}$ More generally, on this view the value of the invention is its incremental value over the patented alternative, ignoring the royalties that would have to be paid to use that alternative, on the rationale that those royalties do not reflect the value of the alternative technology but merely the value of the patent right. ${ }^{59}$ By the same token, if the infringed technology were not quite as good as the patented alternative, the value of the infringed technology would be zero. We recommend rejecting this approach, on the ground that although it makes sense from a static welfare perspective, it provides a facially inadequate incentive to invent (zero compensation) and therefore appears inconsistent with the conventionally understood purpose of the patent system.

Another possibility would be to assume that a patented alternative that is on the market is

\footnotetext{
${ }^{56}$ In the standards context it also quite likely that in practice all the relevant technologies will be patented, precisely because of the incentive provided by the prospect of being included in the standard; see, e.g., Layne-Farrar 2014 (discussing the competition among patentees to have their technology included in the standard).

${ }^{57}$ Consider, for example, the near-simultaneous invention of Viagra (sildenafil) and Cialis (tadalafil).

${ }^{58}$ Swanson \& Baumol 2005, 10-21 (auction model).

${ }^{59}$ Taylor 2014, 161.
} 
available for its established market price, which is normally above marginal cost. Put another way, "[t]he proper comparison is between the cost and value of the patentee's component and the cost and value of the alternative, including patent royalties that would have to be paid on the alternative where appropriate." 60 This approach has some support in the case law, though it cannot be considered established law. ${ }^{61}$ Nevertheless, although this approach might seem appealing when both technologies are mature and both have an established price, it might be difficult to apply if both technologies are new to the market and neither has an established price. This suggestion is therefore likely to be unhelpful in the SEP context, where alternative technologies competed for inclusion in the standard ex ante, and the alternative that was not selected may not have a market presence at all ex post, or will have a value that is much lower than if it had been selected for inclusion in the standard. Another problem arises when the alternative technology is mature and has an established price, and the infringed technology is new. If the technologies are close substitutes, we would expect the new technology to drive down the price of the established technology, even in the absence of infringement. Thus, if the established price of the alternative is used for comparison purposes, the patentee will be overcompensated in comparison with the royalties it would have received but for the infringement. Perhaps, then, the proper approach in principle would be to assess how the price of the patented alternative would have evolved in response to the introduction of the infringed technology, in the absence of infringement. On the other hand, simply using the established price has clear advantages in terms of ease of proof.

\footnotetext{
${ }^{60}$ Lemley \& Shapiro 2007a, 2039, n.153.

${ }^{61}$ See In re Innovatio IP Ventures, LLC Patent Litigation (N.D. Ill. 2013, p.20) (U.S.) (stating that the court would consider patented alternatives, but "that they will not drive down the royalty in the hypothetical negotiation by as much as technology in the public domain”).
} 
We are not aware of any literature providing a thorough theoretical analysis of this problem. ${ }^{62}$ We therefore propose further research on this issue.

\section{B. Hypothetical Bargain}

In the United States, the most common approach to assessing a reasonable royalty is usually referred to as the "hypothetical negotiation" approach: ${ }^{63}$

The hypothetical negotiation tries, as best as possible, to recreate the ex ante licensing negotiation scenario and to describe the resulting agreement. In other words, if infringement had not occurred, willing parties would have executed a license agreement specifying a certain royalty payment scheme. ${ }^{64}$

While this approach is now deeply entrenched, the leading cases emphasize that the goal of the hypothetical negotiation framework is not to replicate the bargain that actual willing parties would have arrived at; that would be "inaccurate, and even absurd," 65 given that "[t]here is, of course, no actual willingness on either side, and no license to do anything, the infringer being normally

\footnotetext{
${ }^{62}$ For a brief discussion, see Siebrasse \& Cotter 2017a.

${ }^{63}$ Lucent Techs., Inc. v. Gateway, Inc. (Fed. Cir. 2009, p.1324) (U.S.). It is also sometimes referred to as a “hypothetical bargain” or “willing licensor/willing licensee” approach.

${ }^{64}$ Id. at 1325.

${ }^{65}$ Rite-Hite Corp. v. Kelley Co. (Fed. Cir. 1995, p.1554 n.13) (U.S.) (en banc).
} 
enjoined. . . from further manufacture, use, or sale of the patented product.”66 The hypothetical negotiation is a "legal fiction," 67 "employed by the court as a means of arriving at reasonable compensation," 68 and it is to be "flexibly applied as a 'device in the aid of justice.”" 69

We recommend that courts embrace this view of the hypothetical bargain framework as a tool—a proxy for the issues of how to split the surplus from the invention—rather than as a goal in and of itself. ${ }^{70}$ For example, it is well-established in U.S. law that the parties to the hypothetical negotiation are assumed to have known that the patent was valid and infringed, even though actual parties would not. This rule is required to achieve just compensation, because the opposite viewthat the parties should be assumed to discount the royalty to allow for the probabilistic nature of the patent (as would presumably be done by parties to an actual negotiation)—-would result in socalled double discounting; ${ }^{71}$ not only would the court-approved royalty derived from the

${ }^{66}$ Panduit Corp. v. Stahlin Bros. Fibre Works Inc. (6th Cir. 1978, p.1159) (U.S.).

${ }^{67} I d$.

${ }^{68}$ Hanson v. Alpine Valley Ski Area, Inc. (Fed. Cir. 1983, p.1081) (U.S.) (quoted with approval in Rite-Hite Corp. v. Kelley Co. (Fed. Cir. 1995, p.1554 n.13) (U.S.)).

${ }^{69}$ TWM Mfg. Co., Inc. v. Dura Corp. (Fed. Cir. 1986, p.900) (U.S.) (quoted with approval in Rite-Hite Corp. v. Kelley Co. (Fed. Cir. 1995, p.1554 n.13) (U.S.)).

70 See similarly Janicke 1993, 726-27 (“The engrafted “assumptions” of validity, infringement, and business information would be better viewed as reminders to the decisionmaker on reasonable royalty to help him or her reach a just result, rather than as facts artificially deemed “known” at an artificial negotiation.”).

${ }^{71}$ Cotter 2013a, 135-36; see also Choi 2009, 154-55 (arguing that the use of ex post information is necessary to cure this problem); Taylor 2014, 115-16 (reviewing the development of the law on this point, and arguing that the problem is not only one of double discounting, but circularity, because the discounted value that the parties would negotiate 
hypothetical negotiation include a discount for the risk of non-liability, but then pre-litigation negotiations in which royalties were based on the expectation of such a court award occurring with a less than $100 \%$ probability would include a further discount for risk of non-liability. For that reason, we agree that this well-established principle of U.S. law is sound. Moreover, based on similar reasoning, the hypothetical negotiation should include an assumption of liability, not just validity and infringement, as well as entitlement to relief and enforceability. ${ }^{72}$ And more generally, departures from a strict attempt to reconstruct what real parties would have done had they actually bargained are justified whenever such a departure would be a better means of arriving at reasonable compensation — in particular, compensation which reflects the value of the patented technology over its best non-infringing alternative. Indeed, if sound principles of reasonable compensation require an unwieldy number of departures from a hypothetical negotiation framework, the proper course would be to abandon the framework rather than the sound principles. ${ }^{73}$

would itself then be reflected in the damages award, and the parties, anticipating this, would further discount the negotiated price, and so on).

72 Taylor 2014, 127-29.

${ }^{73}$ See Janicke 1993, 726 (suggesting that "In view of the increasing number of assumptions engrafted onto the underlying fiction of hypothetical negotiation, the Federal Circuit should consider whether the time has come to abolish the fiction altogether. ...”); Taylor 2014, 125-26. Similarly, although real-world negotiations sometimes might result in a degree of royalty stacking in cases involving complex products, for purposes of awarding reasonable royalties courts could make the assumption that the parties would have bargained to avoid this outcome, in order better to align royalties with the value of the technology. See Page 2014. 


\section{Dividing Incremental Value}

The second and third parts of Step 1 involve identifying the appropriate division of the incremental value. Both sides often can make a substantial claim to at least a portion of the incremental value - the patentee because this value results from use of the claimed invention, and the adjudged infringer because it made complementary or supplementary investments that resulted in a commercial embodiment of that invention. How then should the value be divided?

In theory, an invention can give rise to pure economic rents, reflecting the value of the invention over the best non-infringing alternative. If two parties, such as a patent owner and an licensee, must cooperate to realize those rents, there is no simple theoretical answer as to how the parties will split the rents between them, since even a very lopsided split, in either direction, would leave both parties better off as compared with using the non-infringing alternative. The most prominent solution to the problem is the Nash Bargaining Solution (NBS), which implies a 50/50 split. However, the NBS requires unrealistically restrictive assumptions about the parties, such as that they are identical in every way. Economic theory is relatively underdeveloped in terms of fleshing out how pure rents would be split when the parties are modeled more realistically. ${ }^{74}$ The Nash Bargaining Solution is sometimes used, not because it is a particularly accurate model, but for lack of anything better.

Moreover, the division of the incremental profit due to the invention is unlikely to be a

\footnotetext{
74 The main theoretical refinement is by Ariel Rubinstein, who shows that under certain conditions, a party with a higher discount rate (higher time value of money) will have less bargaining power. Rubinstein 1982.
} 
split of pure rents. Turning a patented invention into a commercialized innovation which actually commands a premium in the marketplace, requires some or all of manufacturing, distribution, marketing, process refinement, technical support to the licensee by the patentee, end-user support, and so on, all of which involve risk and investment by one party or the other. The royalty paid by the licensee to the patentee does not reflect a split of pure rents, but also, or even instead, compensation to the party who made the investments and shouldered the risks relating to these ancillary services. ${ }^{75}$ Georgia-Pacific factor 13 recognizes this possibility, ${ }^{76}$ as have cases such as Tights, Inc. v. Kayser-Roth Corp.:

The Court finds, in the context of this case, that the patentee would have been reasonably entitled to receive from $25 \%$ to $50 \%$ of the cost saving as reasonable royalties. This Court finds that $25 \%$ of the cost saving is a reasonable entitlement

75 See Siebrasse \& Cotter 2016, 954-55:

In an actual license agreement, both parties bring something to the table in the process of turning an invention into a commercially valuable revenue-generating product. The patentee's most obvious contribution is the invention, but bringing the final product to market generally requires further development and technical implementation, such as clinical trials, as well as marketing, manufacturing, and distribution, all of which require further investment at risk beyond the investment made by the patentee in the invention itself. Either of the parties may provide these further services, and the way the parties split the incremental profit in an actual negotiation depends on who provides what services and the relative importance and cost of those services.

${ }^{76}$ Georgia-Pacific Corp. v. U.S. Plywood Corp. (S.D.N.Y. 1970, p.1120) (U.S.) (“13. The portion of the realizable profit that should be credited to the invention as distinguished from non-patented elements, the manufacturing process, business risks, or significant features or improvements added by the infringer.”). 
where the parties anticipate that the licensee will have to make substantial contributions to practical commercialization. This Court finds that $50 \%$ of the cost saving is a reasonable entitlement where the parties anticipate that the licensee will have to make only routine creative contributions toward commercialization. ${ }^{77}$

We therefore recommend that, to the extent possible, the split of the incremental profit should reflect the value of any such ancillary services or risks that either the patent owner or the infringer, in fact, undertook. In our view this is consistent with the hypothetical bargaining construct because it reflects the agreement the parties themselves would have arrived at in similar circumstances. Recall that the principal justification for the hypothetical bargain is that it preserves the patent incentive by restoring the patent owner to the position it would have occupied absent the infringement. That position would depend in part on how the parties would have agreed, ex ante, to divide the value to be derived from the use of the patented invention, in comparison with alternatives. However, we emphasize that we recommend taking such services into account to the extent they are actually incurred. Even if an actual licensee would have provided marketing for the invention, and an actual royalties would have reflected that value, the reasonable royalty award should only reflect that if in fact the infringer undertook the marketing. ${ }^{78}$

More broadly, we propose further research to unpack and refine the nature of "bargaining power” as it relates to the division of the incremental value of the invention. ${ }^{79}$ We suspect that the

\footnotetext{
77 Tights, Inc. v. Kayser-Roth Corp. (M.D.N.C. 1977, p.164) (U.S.).

${ }^{78}$ See Siebrasse \& Cotter 2016, 989-90

${ }^{79}$ In economic theory, "bargaining power” is used largely as a label rather than an explanatory variable. If the observed split is $80 / 20$, and there is no evident reason for an uneven division, then we say that one of the parties has greater
} 
division in any given case is determined in part by compensation for ancillary services and in part by industry norms (which may themselves reflect reflect standard practices about provision of ancillary services). To some extent this unpacking is a matter of obtaining better evidence as to what factors actually drive the division of the incremental profit in practice. In addition, there are some conceptual or normative issues to be resolved. In particular, one intuitive understanding of "bargaining power" is that a party with deeper pockets has greater bargaining power, and so would be able to extract a greater share of the incremental value in an actual licensing negotiation. For example, if the patent owner was a small cash-strapped startup, and the potential licensee was a large company, the licensee might in practice be able to the extract very favorable terms. It can be argued that it would be appropriate to replicate that unequal division in a reasonable royalty assessment, on the view that the patentee should not be made better off than it would have been had the parties actually licensed. On the other hand, the favourable terms might be considered to be an illegitimate holdout by the licensee, which should not be replicated in a reasonable royalty, on the view that it does not reflect the incremental value of the invention, just as the courts should not give the patentee a higher royalty if it would have been able to engage in holdup in an actual negotiation. These questions deserve further exploration.

Having decided which factors should be relevant to the division of the incremental profit, and second question is what evidence should be used to establish that division. A few possibilities come to mind. First, comparables may shed light, either explicitly or implicitly, on how the parties would have agreed to divide the surplus. As discussed above, evidence also could reflect any ancillary services or risks that either the patent owner or the infringer, in fact, incurred, so as to

bargaining power than the other. 
adjust the royalty derived from the comparable licence. Second, there may be evidence of what the parties would have agreed to based on their own prior negotiations, the patentee's course of dealing with other parties, or the custom of the industry. To illustrate, in United States Frumentum Co. v. Lauhoff, the U.S. Court of Appeals for the Sixth Circuit held that evidence was admissible as to what share of the profits or of the selling price "it may be customary in that or similar business to allow for the use of such an invention.” ${ }^{80}$ (Of course, questions may arise as to just how similar a "similar business" must be.) When there is no such evidence of how the parties would have agreed to split the incremental value, however, what then? On the one hand, it would seem wrong to award the patent owner nothing — and in any event U.S. law normally would preclude such a result because section 284 of the U.S. Patent Act requires courts to award "damages adequate to compensate for the infringement, but in no event less than a reasonable royalty for the use made of the invention by the infringer." ${ }^{81}$ Indeed, one of the reasons for the gradual adoption of the reasonable royalty remedy in the U.S. in the early to mid-twentieth century was precisely to avoid

${ }^{80}$ U.S. Frumentum Co. v. Lauhoff (6th Cir. 1914, p.617) (U.S.); see also Georgia-Pacific Corp. v. U.S. Plywood Corp. (S.D.N.Y. 1970, p.1120) (U.S.) (listing factor 12, which refers to "[t]he portion of the profit or of the selling price that may be customary in the particular business or in comparable businesses to allow for the use of the invention or analogous inventions,” and is likely based on Frumentum).

${ }^{81}$ U.S. Patent Act, 35 U.S.C. § 284 (emphasis added); see also Apple, Inc. v. Motorola, Inc. (Fed. Cir. 2014, p.1328) (U.S.) (stating that, even when a patent owner fails to introduce admissible evidence quantifying its loss, the court is obligated to “determine what constitutes a reasonable royalty from the record evidence”); Schönknecht 2012, 311-13 (discussing the German courts’ “free discretion” to estimate damages under $§ 287$ of the Code of Civil Procedure, and stating that " $[\mathrm{t}]$ he injured party is not required to prove the exact amount of its damage; rather, it is sufficient if it presents a factual basis on which the court can establish 'at least a rough estimate’ of the damage.”) (citing BGH v. 6.3.1980 - X ZR 49/78 - Tolbutamid (Ger.)). 
situations in which courts could award only nominal damages, due to difficulties in quantifying the owner's loss or the infringer's gain with sufficient certainty. ${ }^{82}$ Rather, as Judge Learned Hand expressed it back in 1933, "[t]he whole notion of a reasonable royalty is a device in aid of justice, by which that which is really incalculable shall be approximated, rather than that the patentee, who has suffered an indubitable wrong, shall be dismissed with empty hands." ${ }^{83}$ By the same token, it would seem equally wrong to award the patentee $100 \%$ of the profit the infringer earned from the use of the claimed invention simply because the infringer couldn't prove the appropriate division (unless the patentee was seeking, and was entitled to under the relevant substantive law, an award of the infringer's profits). ${ }^{84}$

Arguably then, the best practice would be to permit the parties to introduce whatever competent evidence they have on the division of profits, including comparables, while also permitting the factfinder to take note of, for example, findings from behavioral psychology and economics (e.g., the ultimatum game) suggesting that people in Western societies generally view a 50/50 split of benefits as fair. (Similarly, the Nash Bargaining Solution, application of which often may result in a 50/50 split, is a widely used construct in game theory—albeit with economists often employing the 50/50 split as a plausible assumption, rather than substantiating it as an empirical fact of how two actual parties would have bargained) ${ }^{85}$ For example, in Summit 6, LLC v. Samsung Electronics Co., the Federal Circuit recently affirmed a damages judgment based on

\footnotetext{
${ }^{82}$ Taylor 2014, 97-101, 112-113 (describing this history of the development of reasonable royalties).

${ }^{83}$ See, e.g., Cincinnati Car Co. v. New York Rapid Transit Corp. (2d Cir. 1933, p.594-95) (U.S.).

${ }^{84}$ Such awards are no longer available in the U.S. other than in design patent cases, as discussed in Chapter 2.

${ }^{85}$ See, e.g., Henrich 2015, 191-92, 358-59; Stout 2011, 52-54.
} 
an expert witness's purported isolation of the incremental profit Samsung had derived from the use of the patented invention, and his subsequent division of that profit between the parties based on analysis of Samsung's bargaining power and application of the Nash Bargaining Solution. ${ }^{86}$

We therefore recommend that, when faced with the question of how to divide the incremental value derived from the use of the invention over the next-best alternative, courts permit the parties to introduce any competent evidence on this issue-including, where necessary to estimate a royalty "in aid of justice," empirical findings that people in Western societies generally view a 50/50 split of benefits as fair, and that economists often use the Nash Bargaining Solution in modeling bargaining behavior. Further to this point, policymakers may wish to consider adopting a rebuttable presumption that the parties would have agreed to a 50/50 splitwhich presumption, however, should come into play only after there has been an initial determination of the incremental profit derived from the use of the invention, and should not be difficult for the parties to rebut by means of more specific evidence (comparables, industry practice, risk allocation, etc.). ${ }^{87}$

${ }^{86}$ Summit 6, LLC v. Samsung Electronics Co. (Fed. Cir. 2015, p.1297) (U.S.). Compare VirnetX, Inc. v. Apple Inc. (Fed. Cir. 2014, p.1333-34) (U.S.) (disapproving of the use of the Nash Bargaining Solution on the ground that use of a 50-50 split as the proposed starting point for a damages calculation was “insufficiently tied to the facts of the case”).

${ }^{87}$ Various bodies of law, including patent law, make use of presumptions in a variety of contexts in which a fact of interest (call it $X$ ) is difficult to prove but likely correlated with the presence of some other, more easily provable, fact (call it $Y$ ). In such cases, presuming the existence of fact $X$ upon proof of fact $Y$ may reduce adjudication costs and better promote the goal of accurate factfinding than would a rule requiring that, absent competent proof of fact $X$, the trier of fact must find not- $X$. Relatedly, a rebuttable presumption encourages the party against whom the presumption operates to come forward with evidence justifying a departure from the presumption, which makes sense if that party is likely to be better-positioned than its counterpart to have access to such information. For discussion of the function 
By contrast, we would not recommend use of a stronger presumption (e.g., one that can be rebutted only by clear and convincing evidence) out of concern that, inter alia, the trier of fact (particularly a lay jury) might accord such a presumption too much weight. Further, a weak presumption of this sort should be sharply distinguished from the $25 \%$ Rule of Thumb previously used by U.S. courts and rejected by the Federal Circuit in Uniloc USA, Inc. v. Microsoft Corp. ${ }^{88}$ Unlike that rule of thumb, under which a damages expert was permitted to presume that "the licensee pay a royalty rate equivalent to 25 per cent of its expected profits for the product that incorporates the IP at issue,”89 the presumptive value split suggested here would apply only after the incremental profit properly attributable to use of the claimed invention has been isolated from all other portions of overall revenue and profit. In complex product cases, there are likely to be multiple innovations beside the claimed invention that have contributed to overall revenue and profit. Consequently, in such cases, 50\% of the incremental profit attributable to the claimed invention can be expected to often be only a small percentage or even only a small fraction of a percent of the overall profit from the complex product.

\section{Timing of Hypothetical Negotiation}

The standard view in U.S. case law is that the hypothetical bargain occurs just prior to the

and working of presumptions generally, see, e.g., Mueller \& Kirkpatrick 1999, 126-31; McGowan 2010, 582; Posner 1999, 1503-04.

${ }^{88}$ Uniloc USA, Inc. v. Microsoft Corp. (Fed. Cir. 2011) (U.S.).

${ }^{89}$ Goldscheider et al 2002, 123. 
date on which the infringement began. ${ }^{90}$ This timing has been controversial in two main respects. First, it is the basis for the mainstream view in U.S. law that the hypothetical bargain should be based only on information that is available to the parties ex ante, and that ex post information is relevant only as indirect evidence of what the parties would have expected ex ante (the "book of wisdom” approach). ${ }^{91}$ The standard in Germany, by contrast, states that the court should consider the bargain the parties would have reached ex ante had they foreseen all relevant ex post information; ${ }^{92}$ and a few commentators argue for the expanded use of ex post information in U.S. law as well, on the view that this allows for a more accurate valuation of the patented technology. ${ }^{93}$ Second, there is substantial scholarly commentary, particularly in the SEP context, suggesting that the timing of the hypothetical negotiation should be earlier, just prior to the time when sunk costs ${ }^{94}$

${ }^{90}$ See Lucent Techs., Inc. v. Gateway, Inc. (Fed. Cir. 2009, p.1324-25) (U.S.) (stating that "the hypothetical negotiation or the 'willing licensor-willing licensee' approach ... attempts to ascertain the royalty upon which the parties would have agreed had they successfully negotiated an agreement just before infringement began," recreating "as best as possible ... the ex ante licensing negotiation scenario and ... resulting agreement”); Georgia-Pacific Corp. v. U.S. Plywood Corp. (S.D.N.Y. 1970, p.1120) (U.S.). In the SEP context, courts have begun to shift the time frame for the hypothetical negotiations, from just before the patent was infringed to just before the standard was adopted. See In re Innovatio IP Ventures, LLC Patent Litigation (N.D. Ill. 2013, p.19) (U.S.); Microsoft Corp. v. Motorola, Inc. (W.D. Wash. 2013, p.19) (U.S.); Apple, Inc. v. Motorola, Inc. (N.D. Ill. 2012, p.913) (U.S.).

${ }^{91}$ See infra Part III.E.

${ }^{92}$ See Schönknecht 2012.

${ }^{93}$ See Siebrasse \& Cotter 2016.

${ }^{94}$ We use the term "sunk costs" throughout in the economic sense of costs that have been incurred and cannot be recovered, rather than in the accounting sense of fixed costs. 
were incurred; this commentary reflects the view that the user would inevitably have incurred sunk costs by the time of the first infringement, so that a license negotiated at that time would allow the patentee to hold up the user for part of those sunk costs, leading to a royalty in excess of the value of the invention. ${ }^{95}$

With these critiques in mind, we recommend that, to the extent courts continue to employ a hypothetical bargaining construct at all, they should apply a flexible approach that takes into account the hypothetical bargain's status as a legal fiction employed as an aid to arriving at reasonable compensation, rather than as a foundational principle in its own right to be applied strictly and literally. With regard to timing in particular, in many cases the precise date of the hypothetical negotiation does not have any impact on the reasonable royalty, and the early U.S. decisions invoking the hypothetical negotiation approach did not usually specify the time when the negotiation took place. On the other hand, in the cases establishing the time of the first infringement as the appropriate date, courts have chosen the infringement date not because it reflects the time of a negotiation between truly willing parties, but because that timing does justice on the facts of the particular case. As discussed in Parts II and III.E, our preferred approach is not to employ a hypothetical negotiation as such, to identify the surplus that the parties are negotiating over, and to divide that surplus in an appropriate manner. But whichever construct is used, the ultimate goal is to ensure that the division does not reflect lock-in but that it does reflect any ancillary services or risks that either party has shouldered.

To illustrate our recommendation, consider a case in which the court deems the

\footnotetext{
${ }^{95}$ See, e.g., Taylor 2014, 129 (noting that "[t]o avoid extraction of value from patent holdup, the time period for the hypothetical negotiation should be assumed to be just prior to any investment by the infringer in developing or using the patented technology”).
} 
hypothetical negotiation to have taken place at the time of first infringement, but after the infringer has incurred sunk costs. In such a case, the patentee might be able to extract some of the value associated with those sunk costs even if it has no substantial relation to the value of the patented technology, contrary to the consensus view that the patentee normally should not be able to extract such unrelated value. ${ }^{96}$ Fortunately, we are not aware of any cases in which the courts have approved of allowing the patentee to extract value associated with such sunk costs specifically on the basis that this would have happened had the parties bargained on the infringement date. In our view, they key point is to ensure that the evidence used to establish the reasonable royalty avoids problems associated with sunk costs. If, for example, the bargain is constructed using comparable licenses, a strict adherence to the principle that the bargain takes place prior to infringement would bar the use of any comparable licenses entered into after that date. But if the party to the relevant comparable had negotiated its license prior to incurring any sunk costs, then neither that license nor a royalty based on it would reflect sunk-costs holdup, and there would be no reason to reject the use of that comparable based on its date of execution.

Further, while the view that a reasonable royalty should not reflect the infringer's sunk costs is generally sound, it doesn't necessarily require that the royalty be based on evidence that pre-dates those sunk costs. The previous example highlights one such scenario. As another example, often it may be easier to determine the date on which infringement began than the date on which the infringer began incurring sunk costs, in which case-as long as the sunk costs are not too large-the marginal increase in accuracy resulting from moving up the date of the hypothetical negotiation may not be justifiable in view of the additional administrative expense.

\footnotetext{
${ }^{96}$ Unless there is some specific reason for allowing a supracompensatory remedy, such as the need to deal with the problem of opportunistic infringement, as discussed in Chapter 3.
} 
Alternatively, consider the facts of Tights, Inc. v. Kayser-Roth Corp.,${ }^{97}$ in which the court noted that a licensee would pay a lower royalty if it would be required to make substantial contributions to practical commercialization, and a higher royalty if it made less contributions towards commercialization. The timing of the hypothetical negotiation was important because the product market was relatively mature by the time of the first infringement, and so the reasonable royalty was higher than it would have been had the infringer entered a nascent market. ${ }^{98}$ If the bargain date were moved back to avoid sunk costs holdup, this would imply that the reasonable royalty in Tights would have to be reduced correspondingly. In our view, Tights was correctly decided on its facts, and a lower royalty to notionally avoid sunk-costs holdup—which was not in issue —-would be inappropriate.

This illustrates the importance of addressing the underlying issue rather than focusing solely on the date of the hypothetical negotiation. A negotiation date that is appropriate for some purposes (avoiding sunk-costs holdup) may be inappropriate for others (ensuring that the royalty reflects the infringer's contribution to commercialization). Moving the negotiation date back to solve one problem might simply create other problems, when all that is really necessary is to ensure that the specific evidence on which the royalty is based does not inappropriately incorporate sunk costs holdup.

\section{E. Information Set}

\footnotetext{
${ }^{97}$ Tights, Inc. v. Kayser-Roth Corp. (M.D.N.C. 1977) (U.S.).

${ }^{98}$ See id. at 164.
} 
We now turn our attention to the issue of changed information. Suppose that at the time of the first infringement, the parties anticipated that the invention would be a great success, and so they would have contracted for a very high royalty, but in fact the invention was a failure. If the royalty is to be based only on the information that was available to the parties at the time of the first infringement, the damages award would be very high; but if it is based on the knowledge that the invention is in fact worthless, then the royalty would be very low. For example, following a jury trial in 2012, a federal district court entered judgment in the amount of $\$ 1$ billion in favor of Monsanto in a patent infringement dispute against DuPont. This amount reflected the jury’s best estimate of the lump-sum amount that DuPont would have agreed to pay and that Monsanto would have accepted, just before the infringement began, even though DuPont never sold any of the infringing seed at all. ${ }^{99}$ Notably, the opposite story may also be told. A technology expected to be worthless may prove to be valuable. The mainstream view in U.S. law nevertheless is that ex post information can be used only to establish what the parties believed at the time of first infringement, and if it can be established that their views turned out to be wrong, then the reasonable royalty will be calculated on the basis of those wrong views, and not on the basis of what actually transpired.

We recommend, however, that contrary to the mainstream U.S. approach courts should adopt what Siebrasse and Cotter refer to as the "contingent ex ante approach" under which the hypothetical negotiation is generally assumed (subject to the caveats noted in the preceding section) to take place before any sunk costs are incurred, but with the benefit of ex post information. ${ }^{100}$ The rationale for this approach is that the bargain must be assumed to take place

\footnotetext{
${ }^{99}$ Monsanto Co. v. E.I. DuPont De Nemours \& Co. (E.D. Mo. 2013) (U.S.). No reported opinion following the entry of judgment, and the case settled shortly thereafter. For discussion, see Chao \& Gray 2013.

100 See Siebrasse \& Cotter 2016; Sidak 2016a. The Sedona Conference also discusses expanded use of ex post
} 
ex ante, so that the patentee is not entitled to extract any holdup value; but at the same time, using ex post information more accurately reflects the true incremental value of the invention, and so provides a more accurate reward to the patentee. This is not really inconsistent with a hypothetical negotiation framework, because parties often negotiate on a contingent basis. For example, it is routine to negotiate a running royalty, the effect of which is to make the return to the patentee contingent on ex post information. Using ex post information in the hypothetical negotiation posits that the parties would contract on a broadly contingent basis, taking into account all relevant factors, not just the volume sold. This approach would not exclude evidence that the parties actually would have agreed upon a lump sum royalty, but merely presumes that the parties would have preferred a royalty that took into account the risk of lack of success of the patented technology. This approach is also consistent with the established rule that the parties to the hypothetical negotiation are assumed to know that the patent is valid and infringed even though during actual negotiations they would have discounted the royalty for risk of non-liability.

This view also has some support in U.S. case law, most prominently in the statement by Justice Cardozo in Sinclair Refining that:

An imaginary bid by an imaginary buyer, acting upon the information available at the moment of the breach, is not the limit of recovery where the subject of the bargain is an undeveloped patent. Information at such a time might be so scanty and imperfect that the offer would be nominal. The promisee of the patent has less than fair compensation if the criterion of value is the price that he would have

information: see Sedona Conference 2016, 22-28. Note, however, that as discussed in the preceding subsection, there may be cases in which the timing of the hypothetical negotiation to avoid sunk costs may not be particularly relevant. 
received if he had disposed of it at once, irrespective of the value that would have been uncovered if he had kept it as his own. ${ }^{101}$

This is often said to reflect only the principle that ex post information may be used as evidence of what the parties would have believed at the time of the first infringement, but on its face it supports the use of ex post information more generally. Similarly, in Georgia-Pacific, the district court actually did consider post-infringement evidence, and on appeal the Second Circuit held that the district court had not erred in so doing. ${ }^{102}$ More recently, it appears that the courts have begun to be more liberal in the use of ex post evidence. ${ }^{103}$

On the other hand, one objection to the use of ex post information is that courts have tended to invoke the "book of wisdom" asymmetrically to benefit patentees but not infringers. ${ }^{104}$ One obvious response to this objection is that it is wrong to do so. Presumably clarifying that the use of ex post evidence is generally permissible would help avoid an unprincipled asymmetric approach. ${ }^{105}$ Lee and Melamed further argue that using ex post information substantively, rather

${ }^{101}$ Sinclair Ref. Co. v. Jenkins Petroleum Process Co. (U.S. 1933, p.699) (U.S.).

${ }^{102}$ Georgia-Pacific Corp. v. U.S. Plywood Corp. (2d Cir. 1971, p.297) (U.S.).

${ }^{103}$ See Lee \& Melamed 2016, 414 (reviewing the cases and suggesting that "following [Fromson v. W. Litho Plate \& Supply Co. (Fed. Cir. 1988, p.1575) (U.S.)], courts have regularly relied on the book of wisdom doctrine to permit the consideration of ex post developments, regardless whether those ex post developments provided any insight into the parties' ex ante bargaining positions or whether the case involved willful infringement.”).

104 See Janicke 1993, 725-27.

${ }^{105}$ See id. (criticizing the court for using ex post information asymmetrically, and arguing that the appropriate response is to formally recognize that "the court should examine the business realities at the time infringement began and 
than merely as evidence of what the parties would have known or believed at the time of the first infringement, leads to two mistakes:

First, the rationale assumes that the actual profits would have been unforeseen entirely at the time of the hypothetical negotiation, when the parties negotiating ex ante would likely have understood that there would be a range of possible outcomes (some leading to higher profit and some leading to little or no profit for the infringer) and would have taken all of them into account in selecting a reasonable royalty ex ante. Second, ... . a royalty determined on the basis of ex post evidence will generally include a premium based on ex post economic developments that increase the infringer's reliance on the patent-in particular, lock-in costs-and that are unrelated to the incremental benefit the patent confers.

The first objection, however, misses the point. When the parties' expectations are accurate ex ante, there is no difference between an approach which uses ex post information and one which does not. ${ }^{106}$ The rationale for the use of ex post information is that it allows more accurate determination of the royalty when the parties are mistaken. The second objection is sound so far as it goes, though it actually applies equally to the standard position that the negotiations are assumed to take place at the time of first infringement, by which time the infringer will normally have already incurred lock-in costs. The response is the same whether or not ex post information is to be taken into subsequently, independent of any theory that a hypothetical negotiation has occurred.”).

${ }^{106}$ Unless there is a bias in which cases get litigated: see Siebrasse \& Cotter 2016. 
account; it is to refuse to award royalties that reflect lock-in costs. Put another way, Lee and Melamed implicitly assume that in order to take into account ex post information, it is necessary to assume that the hypothetical negotiation takes place ex post; but under the Siebrasse and Cotter proposal, the hypothetical negotiation is assumed to take place before sunk costs have been incurred, but in light of all ex post information, not just information regarding validity and infringement.

In short, rather than excluding ex post information entirely, the better response is to clearly articulate the rationale, which is not simply to increase the patentee's reward, and thereby make it clear that ex post information is admissible no matter what effect it has on the reasonable royalty damages. Consequently, we are of the view that the contingent ex ante approach is sound.

\section{F. Comparable Licenses}

If we imagine a reasonable royalty as the product of a hypothetical negotiation between the parties using certain assumptions, the use of comparable licenses—what similarly situated parties “did in fact agree to" ${ }^{107}$ _as an aid in making this determination seems quite sensible. ${ }^{108}$ Indeed,

${ }^{107}$ Durie \& Lemley 2010, 641; see also Masur 2015, 120 (“At first blush this approach makes sense; if the courts must reconstruct a hypothetical royalty negotiation, actual preexisting royalty agreements might well constitute the best available evidence of the contours of such a negotiation. Not surprisingly, scholars, commentators, and courts nearly unanimously bless the use of existing licenses to calculate patent damages.”).

${ }^{108}$ The first two Georgia-Pacific factors, for example, focus specifically on prior licensing agreements. See GeorgiaPacific Corp. v. U.S. Plywood Corp. (S.D.N.Y. 1970, p.1120) (U.S.) (listing "1. The royalties received by the patentee for the licensing of the patent in suit, proving or tending to prove an established royalty" and "2. The rates paid by the licensee for the use of other patents comparable to the patent in suit”). Other factors refine the relevance of prior 
when a license meets the stringent requirements to qualify as an "established" one, its probative value might seem clear. ${ }^{109}$ There are nonetheless significant practical and conceptual problems involved with using comparable licenses_even "established" ones ${ }^{110}$ —as evidence of a reasonable royalty. Although we do not suggest that courts should forgo the use of comparable

licenses by adding context. For example, the third and fourth factors consider the nature of the patentee's licensing program by weighing the exclusivity of the prior licenses and any geographic restrictions or other special conditions found in them. See id. Courts outside the United States also frequently look to comparable licenses, or sometimes industry standard rates, as an aid in calculating reasonable royalties. For discussion of practice in Germany and Japan, see Cotter 2013a, 268, 321-22; Second Subcommittee of the Second Patent Committee 2014. Our discussion in the text above to "comparables" therefore should be understood to apply to other analogous forms of evidence, such as industry standard rates.

${ }^{109}$ Dowagiac Mfg. Co. v. Minn. Moline Plow Co. (U.S. 1915, p.648) (U.S.) (stating that where the patentee undertakes “a course of granting licenses” then those "established royalties ... [afford] a basis for measuring damages”); Rude $v$. Westcott (U.S. 1889, p.164-65) (U.S.) (stating that, to qualify as an established royalty, the rate "must be paid or secured before the infringement complained of," "must be paid by such a number of persons as to indicate a general acquiescence in its reasonableness by those who have occasion to use the invention," "must be uniform at the places where the licenses are issued,” and should not be paid in settlement of another infringement claim); Nickson Indus., Inc. v. Rol Mfg. Co. (Fed. Cir. 1988, p.798) (U.S.) ("Where an established royalty exists, it will usually be the best measure of what is a 'reasonable' royalty”).

${ }^{110}$ See, e.g., Consol. Rubber Tire Co. v. Diamond Rubber Co. of NY (S.D.N.Y. 1915, p.459) (U.S.) (describing the inappropriateness of awarding established royalties in circumstances where the licensed patent was widely believed to be invalid); Taylor 2014, 101-04 (explaining that, "[i]n an unbroken line of succession, later courts have followed Judge Hand's reasoning [in Consol. Rubber Tire Co.] by awarding reasonable royalties rather than diminished royalties established during periods of ‘disrepute’ and ‘open defiance’ of patents”). 
licenses, we recommend that courts should be aware of the problems discussed below, and to the best of their ability take these considerations into account when using comparables.

\section{Comparability}

The most obvious hurdle in using comparable licenses is to ensure comparability. It is rare to find actual licenses entered into in exactly the circumstances of the hypothetical negotiation. In theory, a license may be sufficiently comparable to be considered as evidence of a reasonable royalty even though it was not negotiated in circumstances exactly corresponding to the hypothetical negotiation, though adjustments then may have to be made to allow for the differences. And if the license is too dissimilar, it may be properly excluded-particularly in U.S. practice, in which judges play an important gatekeeper role by excluding evidence from consideration by juries.

While licenses involving different patents for related technologies may in principle be useful comparators, there are evident problems in determining whether a different technology is sufficiently comparable. Consequently, courts prefer to rely on licenses granted by the patent owner for the same patent, ${ }^{111}$ but even then problems arise. Licenses often bundle many patents together, including the patent of interest, which makes it difficult to separate out the value of the

111 See Masur 2015, 123-24 (noting the difficulties with using different technologies); see also Cotter 2011,748 ("Strictly speaking, then, for a license to be economically comparable it should relate to the same patent or patents at issue . . . .”); Weinstein et al. 2013, 553 (“In view of ResQNet and Lucent, comparable licenses can only include licenses to the patent-in-suit itself, essentially removing from consideration licenses contemplated under GeorgiaPacific Factors 2 and 12.”). 
technology protected by the patent in suit. Licenses involving technology transfer, as opposed to a mere promise not to sue, routinely include other forms of supporting IP such as trademarks or trade secrets relevant to the patented technology, as well as other obligations on both sides such as grantback clauses or obligations to provide ongoing technical support. In litigation, the hypothetical negotiation concerns a very different transaction, often one involving a bare license to the patent itself. Nevertheless, it may be possible to make adjustments to compensate for the value attributable to other factors. ${ }^{112}$ At least U.S. courts appear generally well-attuned to this problem, and commonly exclude licenses including substantial non-patent benefits. ${ }^{113}$

Moreover, even licenses to the same patent with similar ancillary clauses are not necessarily comparable in terms of the royalty, because patentees are likely to price discriminatethat is, to charge different users prices that reflect the variation in value among those users. ${ }^{114} \mathrm{~A}$ few square centimeters of Gore-Tex may save a life when used in a vascular graft, while a square meter of it may be needed for added comfort in a rain jacket. If the patent owner charged the same amount per unit area to the raincoat manufacturer as to the stent manufacturer, it would either forego substantial profits on the license for the stent, or forgo the raincoat license entirely. Price discrimination is consistent with the principle, enunciated at the outset of this chapter, that the patentee should be entitled to a reward commensurate with the value of its technology over the

\footnotetext{
${ }^{112}$ See, e.g., Microsoft Corp. v. Motorola, Inc. (W.D. Wash. 2013, p.79-92) (U.S.) (quantifying the value to Microsoft of access to the technology in the pool); Unwired Planet Int'l Ltd. v. Huawei Techs. Co. (Pat 2017) (UK) (awarding FRAND royalties based on adjustments to the royalties earned by the assignor of the relevant patent families).

${ }^{113}$ See Hovenkamp \& Masur 2017, 407 n.48.

${ }^{114}$ See, e.g., id. at 12.
} 
next-best alternative. If that value varies between applications, the patentee is likely to charge a different price for those applications. This means that the royalty in a license for the use of the patented technology in a raincoat is probably not a valid comparable in litigation of the use of the technology in a stent, even if the ancillary clauses and even the licensee is exactly the same. (Indeed, even licensees that manufacture both stents and raincoats may well pay a different royalty to the patentee for the different uses. ${ }^{115}$ ) Similarly, a patentee may also price discriminate between different users, even for the same application, if for example one of the users has access to complementary technology while the other does not. ${ }^{116}$

\section{Circularity}

Another possible problem with using comparable licenses is circularity. Because the use of comparables to determine a reasonable royalty is one of the most predictable aspects of a reasonable royalty assessment, one would expect the parties to anticipate the use of comparables if the matter were to proceed to litigation, and to factor this into their bargaining. Thus, if there is any systematic and predictable error in the courts' assessment of the royalty, this error will then be amplified through the use of comparables. Moreover, circularity can arise even if the parties never litigate, as it depends only on the parties’ expectation of the litigation outcome. ${ }^{117}$

\footnotetext{
115 See Samsung Elecs. Co. v. Apple Japan LLC (IP High Ct. 2014, p.134) (Japan) (awarding different royalties for the same technology to the same manufacturer of phones and tablets).

${ }^{116}$ See Hovenkamp \& Masur 2017, 395-96.

117 See Masur 2015, 133; Taylor 2014, 112-15.
} 
Circularity can come in two distinct forms, which we will refer to as "holdup/holdout circularity" and "probabilistic circularity." First, if the prior licenses being used as comparables were negotiated in circumstances where the licensee was subject to holdup or the patentee subject to holdout, the comparable will reflect holdup or holdout value, not just the value of the patented technology over the non-infringing alternative. ${ }^{118}$ One cure for holdup circularity would be to eliminate the risk of holdup itself by denying injunctive relief, though the question of whether denying injunctions in a broader class of cases is desirable, is a significant issue in and of itself (and one that probably shouldn't be driven by the problem of holdup circularity). Alternatively, courts can avoid holdup circularity even if they grant injunctions by excluding evidence of licenses that were negotiated in circumstances giving rise to holdup. This implies excluding evidence of licenses that were negotiated after the licensee had incurred sunk costs. But this may not be easy, as it requires knowledge not just of the prior license itself, but the circumstances under which it was negotiated. In addition, Lemley and Shapiro argue that a form of holdup arises when the user would have had to keep its product off the market after litigation to allow for redesign, and this form of holdup also can be magnified by circularity. This "redesign holdup circularity" can be avoided by excluding licenses negotiated in those circumstances, but this rule too would seem difficult to implement, since it would require knowledge of what the licensee would have thought

\footnotetext{
${ }^{118}$ See Shapiro 2010, 314-15; Lemley \& Shapiro 2007a, 2021-22. As discussed in the Chapter 4, the Lemley \& Shapiro model assumes that a court will always grant a permanent injunction to the successful patentee, and reasonable royalties for the prejudgment infringement. The longer the trial takes as a proportion of the term of the patent, the greater the effect of the reasonable royalty on the litigation outcome, and so the larger the multiplier. In Shapiro's formal model, if litigation always takes the same amount of time, the circularity effect will result in a multiplier that is inversely proportional to the post-trial patent term. See Shapiro 2010, 314.
} 
its best option was in the counterfactual world in which its licensing negotiations failed. The problem of redesign holdup circularity nevertheless can be mitigated if stays are normally granted to allow redesign, as discussed in Chapter 4 on injunctions. ${ }^{119}$

A different kind of circularity can arise due to the probabilistic nature of patents. As discussed in Part III.A, parties to an actual negotiation would discount the value of the patented technology by the probability of liability, thus potentially giving rise to the double discounting problem if courts use a negotiated royalty as the basis for a reasonable royalty. (The doublydiscounted reasonable royalty awarded by the court then would serve as background to the negotiation of the next license, which would then be trebly discounted and so on. ${ }^{120}$ ) In contrast with the problem of holdup circularity, which potentially inflates negotiated royalties as compared with the benchmark value of the patented technology, this problem of "probabilistic circularity" deflates negotiated royalties as compared with the benchmark. (Note too that it is likely to infect even established royalties, notwithstanding their more elevated status in the hierarchy of comparables as noted above.) Furthermore, unlike holdup circularity, which does not arise if the parties do not anticipate that a permanent injunction will be granted, probabilistic circularity arises whether or not the parties expect a permanent injunction to be granted.

Conceivably, holdup circularity and probabilistic circularity may offset one another in

\footnotetext{
${ }^{119}$ Lemley and Shapiro also argue that the probabilistic nature of patents can give rise to holdup can occur, even when a license is negotiated ex ante: see the discussion of "probabilistic holdup" in Chapter 7, Part III.A.4. Probabilistic holdup, however, does not result in circularity, because the overcharge arises because the potential licensee's threat point is not to use the patented technology entirely; that is to say, the licensee acts as if the patent was valid and infringed. But that is the appropriate assumption once validity and infringement have been established at trial.

${ }^{120}$ See Taylor 2014, 115-16.
} 
some cases, but given the difficulty in assessing the magnitude of both types of circularity, it will be impossible to determine the degree to which this is so. The most that might be said is that when the prior license involved a license to a patent which was not already known to be valid and infringed, and it was negotiated after the licensee had incurred sunk costs, the negotiated royalty might be too high or too low, depending on which effect dominates.

In principle, the problem of probabilistic circularity can be avoided by suitably enhancing the actual royalties to compensate for discounting. ${ }^{121}$ There are two problems with this response, however. The first is that, in practice, it seems that such an enhancement is rarely made. ${ }^{122}$ The second, and more fundamental, problem is the difficulty of making an appropriate adjustment. The ideal multiplier would turn on the belief of the parties to the comparable license as to the probability of liability at the time they negotiated the license. But this will be very hard to prove, as it turns "upon private information, available only to the parties to the first licensing agreement, about the plaintiff's probability of success in litigation." ${ }^{123}$ The information may not exist at all outside the minds of the negotiators, and because the prior licensee is not a party to the current litigation, any internal memoranda shedding light on the licensee's view of the probability of liability probably wouldn't be discoverable. (In some cases, the patentee's internal memoranda might shed light on the issue, but even using this information would be problematic, as it would

\footnotetext{
${ }^{121}$ See id. at 130-31.
}

122 See Masur 2015, 132 n.76; Taylor 2014, 144-48 (explaining why this is so). For a rare exception, see St. Lawrence (E.D. Tex. Feb. 21, 2017) (permitting St. Lawrence's expert to offer an opinion that the royalty rate that St. Lawrence had previously negotiated with Samsung for the use of the patents in suit in the pending case against ZTE and Motorola should be increased by $50 \%$ to reflect a "settlement discount” and $18 \%$ to account for an "invalidity discount”).

${ }^{123}$ Masur 2015, 120; see also Taylor 2014, 147. 
normally represent only the patentee's view. ${ }^{124}$ ) And in any event, this inquiry would require timeconsuming and expensive satellite litigation. An alternative would be for the court to try to estimate the discount based on objective factors relative to the particular prior license, such as the testimony of experts as to the probability of liability. But this would be a difficult inquiry on a new issue which would not otherwise have to be litigated, and which does not seem especially susceptible to the production of reliable results. ${ }^{125}$ Thus, in many situations, courts might be better off without adjusting for the implicit discount, and instead simply being mindful that the comparable license provides “a floor for valuing the patent, not [necessarily] a reasonable estimate.”"126

Finally, one could imagine using a standard multiplier. For example that if "any given patent owner has a $25 \%$ chance ex ante of prevailing against any given alleged infringer, then the appropriate multiplier is four." ${ }^{\text {227 }}$ But a standard multiplier not calibrated to evidence of discounting in a particular case merely recasts the circularity problem. ${ }^{128}$ This is because a standard

${ }^{124}$ Though it is not unreasonable to assume the patentee's estimated probability of liability would be in the same ballpark as the licensee's, or they would not have been able to come to an agreement.

${ }^{125}$ See Masur 2015, 149-52 (arguing persuasively that an inquiry of this type would be unsatisfactory); Taylor 2014, 147-48 (same).

${ }^{126}$ Masur 2015, 131.

${ }^{127}$ Id. at 149-52; see also Taylor 2014, 146 ("If infringement and validity are independent variables, then the multiplier resulting from the assumption of liability should be four; that is, the jury should multiply the negotiated royalty reflecting $50 \%$ probability of validity and $50 \%$ probability of infringement by four to obtain a reasonable royalty reflecting certainty as to liability.”).

${ }^{128} \mathrm{~A}$ separate problem with the standard multiplier is that it would probably not be admissible in U.S. law as not being tied to the facts of the case. See Masur 2015, 146. Regardless, even in instances of reliable evidence tied to the facts 
multiplier will overcompensate patentees with strong patents. Anticipating this, parties bargaining in the shadow of the expected trial outcome will negotiate a royalty based on the inflated damages value, and that inflated royalty will feed back into future awards, and so on. ${ }^{129}$ This would result, in effect, in a new source of holdup which would allow a patentee with a strong patent to extract more than the value of its invention. The same spiral would happen in the other direction with patents that are weaker than average. ${ }^{130}$

It therefore would appear very difficult in most cases to reliably enhance the actual royalty arrived at in prior comparable licenses, even though the licenses are themselves otherwise very similar to that at issue in litigation. An alternative approach would be to try to select licenses in which the royalty was not discounted, because they were negotiated in circumstances in which the probability of liability is high. One example would be licenses negotiated after a patent had been held to be valid in other litigation. But even then, the previous judgment of validity wouldn't be binding in litigation involving a different infringer, so it's likely there would still be some discount for the probability of invalidity. And unless the implementation was exactly the same (as might be the case in the SEP context), there might be substantial discounting as to infringement as well, let alone discounting due to risks of invalidity or unenforceability. Further, this approach would

of the case, there is reason to think a jury in particular would not use an appropriate multiplier. Taylor 2014,146 (“[D]oes anyone really think that in a close case a jury will multiply pre-litigation royalties by four, while in a case of blatant liability a jury will not increase pre-litigation royalties at all?”).

${ }^{129}$ For example, if the parties to the actual negotiation thought there was a $90 \%$ chance of liability, the royalty in the prior comparable license will hardly be discounted at all, and a reasonable royalty based on that prior license, augmented by a standard multiplier of four, will therefore be almost four times too large. See Masur $2015,154$.

130 See id. at 155. 
severely restrict the cases in which comparables could be used.

In the same vein, some authors have suggested that prior settlements, which courts in the U.S. normally (though not always) exclude from evidence, ${ }^{131}$ actually should be preferred, particularly if the settlement was entered into when the patent owner appeared to be winning the underlying litigation. ${ }^{132}$ This proposal is again only helpful in a relatively narrow range of cases, as prior settlements are not always available. Moreover, it must be clear that the patentee was winning on the basis of objective factors, such as preliminary motions favoring the patentee, or the discounting problem will not be addressed. ${ }^{133}$ Further, if the patentee in the prior litigation would have expected to obtain an injunction if successful, the settlement may reflect holdup value-thus solving the problem of probabilistic circularity at the expense of inviting the problem of holdup circularity. Another concern with settlements is that they may reflect the value of avoiding litigation costs rather than the value of the patented technology, though this would be a significant problem only when litigation costs are at least comparable to the value of the patented technology. ${ }^{134}$

${ }^{131}$ See, e.g., Rude v. Westcott (U.S. 1889, p.164) (U.S.); but see ResQNet (Fed. Cir. 2010, p.868) (approving use of settlement as a comparable, on the facts of the case); Narechania \& Kirklin 2012.

${ }^{132}$ See Taylor 2014, 131 (making suggesting that "to the extent settlement agreements reflect more certainty regarding liability, economists may be able to use them, rather than other agreements, to identify more easily the true value of patented technology”). This suggestion is more fully developed by Masur 2015, 145-46. See also Prism Techs. (Fed. Cir. 2017) (approving the use of a settlement license on the facts of the case, and discussing the circumstances under which settlements are more or less likely to be probative).

133 See Masur 2015, 145-46, 148.

${ }^{134}$ In such a case, it may even be that the royalty will be too low, not too high. If the patent is weak, litigation value 


\section{Dynamic Considerations}

Some of these problems are likely to get worse in contexts where patentees can predict that a reasonable royalty will be the primary remedy, because we would expect them to adjust their licensing practices to reflect this expectation. ${ }^{135}$ These adjustments might have two kinds of unwanted effects. First, they may make determining accurate damages in the particular case even more difficult. A patentee worried about probabilistic discounting depressing its recovery in future litigation may insist on artificially bundling unnecessary trade secrets or other sham terms into a license solely to ensure that it cannot subsequently be used as a comparable. This is wasteful in itself, though if the parties are careful to include terms that they know are in fact of no value, it will not otherwise distort the transaction. ${ }^{136}$ Another possibility is that a patentee would include self-indulging statements in license agreements about large discounts in light of significant risks of non-recovery. ${ }^{137}$ Conversely, the patentee may try to game the system by negotiating licenses with artificially high rates, in hopes that these will be used as comparables. ${ }^{138}$ This tactic is also

settlement may make sense, but once it is adjudged to be valid and infringed, those low-value settlements no longer reflect the true value of the patented technology.

135 As discussed in the Chapter 4, awarding ongoing royalties in lieu of injunctions generates a risk of error in the calculation of such royalties — though whether such errors systematically favor one party or the other, and whether they are justified in view of the holdup risk resulting from injunctions, are debatable questions.

136 See Hovenkamp \& Masur 2017, 406.

137 Taylor 2014, 149.

138 See Hovenkamp \& Masur 2017, 406-09; Cotter 2018, 195 (noting that this seems to have been the case in Microsoft 
wasteful in terms of increased transaction costs, but again it will not affect the licensing terms more generally if courts can detect and exclude such licenses from being used as comparables (which, however, is debatable).

Second, such adjustments may distort the general licensing behavior of the patentee in ways that will have more general effects. As discussed above, price discrimination means that a patentee will rationally charge a high royalty to a high-value user and a low royalty to a low-value user. But if the patentee anticipates that its license to a low-value user will be used as a comparable in subsequent litigation against a high-value user, it may prefer not to license the low-value user at all. This hurts both parties, and society as a whole. ${ }^{139}$ The cure for this, in principle, would be for courts to exclude licenses negotiated with a low-value user as comparables in subsequent litigation with the high-value user, but it is far from clear that courts could reliably and predictably differentiate the two cases. ${ }^{140}$ And of course, the first step would be for courts to acknowledge the need to do so. Otherwise, the use of comparable licenses to assess reasonable royalties may actually result in restricted licensing of the technology. This would be highly undesirable if it is now, or is likely to become, a problem in practice.

All of this is not to say that comparables are not probative at all, or that the above problems can never be mitigated or avoided. For example, Judge Robart's use of the MPEG LA H.264 patent

\footnotetext{
Corp. v. Motorola, Inc. (W.D. Wash. 2013) (U.S.)).

139 See Hovenkamp \& Masur 2017, 403-04.

140 See id. Note that it is not enough that the courts could make the distinction; they would have to do so in practice with sufficient predictability that the patentee would not need to worry about the low value license affecting its recovery in a high-value lawsuit.
} 
pool rate in Microsoft $v$ Motorola probably did not trigger a serious probabilistic discounting problem, because even if some individual patents in the pool might have been invalid or not infringed, parties to the pool could be highly confident that it was necessary to take a pool license to practice the technology in question. The price discrimination problem also did not appear to arise in that case, because the pool did not price discriminate other than on the basis of volume, ${ }^{141}$ and a pool license would have been available to the infringer. Sunk-costs circularity also probably did not arise because, at least as it appears, the pool rates were set to attract licensees who had not yet incurred sunk costs. Moreover, it may be the case that the circularity problems noted above are more theoretical than practical. Although the annual patent litigation studies produced by PwC and Lex Machina, discussed above in Part I.A, reveal some variations from year to year, there does not appear to be any trend toward consistently higher (or lower) median damages awards in the United States over the past decade. Theoretical difficulties aside, therefore, it may be that courts already are adequately counteracting the potential spiraling effects of circularity.

Overall, then, we recommend that courts should apply comparables and other market evidence with caution. Such evidence often may be the best that is available, and even when there is other evidence of the value of the technology over alternatives, it may still be useful to consider market evidence by way of comparison. Nonetheless, courts probably could make more accurate determinations if more license terms were publicly accessible. We therefore recommend (and

\footnotetext{
${ }^{141}$ See Microsoft Corp. v. Motorola, Inc. (W.D. Wash. 2013, p.78) (U.S.) (stating that “[t]he MPEG LA H.264 patent pool charges royalties to licensees for products that incorporate an H.264 codec according to the following schedule: - the first 100,000 units are royalty-free; • for unit volumes between 100,000 and 5 million, the royalty is $\$ 0.20$ per unit; and • for unit volumes above 5 million, the royalty rate is $\$ 0.10$ per unit.”).
} 
propose further research devoted to) ongoing efforts to encourage such disclosure. ${ }^{142}$

\section{G. Entire market value rule and smallest saleable unit}

Another practical concern that often arises when applying a multifactor approach to reasonable royalties is that the parties may make strategic choices with respect to the royalty base and royalty rate that they present to factfinders. To reach a specific reasonable royalty award, a patentee could argue (or a factfinder could determine) that a relatively small rate should be applied to a relatively large base, or conversely that a relatively large rate should apply to a relatively small base. For example, a $1 \%$ royalty rate applied to a $\$ 10,000$ base and a $25 \%$ rate applied to a $\$ 400$ base both lead to a $\$ 100$ reasonable royalty award.

In theory, it should be irrelevant which method a litigant elects when presenting a damages case in court, and a factfinder should be able to determine an appropriate royalty employing either method. In line with this observation, in many jurisdictions courts routinely use the value of the end product as the royalty base. ${ }^{143}$

\footnotetext{
${ }^{142}$ See, e.g., Contreras et al. 2016 (proposing a study aimed at providing "researchers, litigants, judges, policy makers, regulators and the public with previously unavailable information regarding commercial patent licensing practices, including royalty rates, in a manner that does not compromise firm-level confidential information”); see also Ward 2017 (discussing recent German case law intended to increase the disclosure, subject to confidentiality order, of comparables for use in FRAND licensing disputes).
}

${ }^{143}$ In Germany, for example, even when the patent covers only a portion of an end product, courts consider what reasonable parties would have selected as the royalty base, and often though not invariably use the value of the end product, taking into account such factors as industry custom; the convenience of the parties; whether the invention accounts for all or most of the value of the end product; whether the component is often sold separately; and whether 
In recent years, however, U.S. law has placed limits on patentees’ ability to introduce evidence of the profit or revenue derived from sales of the entire accused product. These restrictions have been motivated at least in part by the long-recognized need to ensure that damages are properly apportioned to the patented features of the accused device, and not to other elements. ${ }^{144}$ Concerns over large bases resulting in overcompensation thus have led the Federal Circuit to articulate a general rule that the royalty base should be the "smallest saleable patentpracticing unit” (SSPPU) in the accused product, and that use of the "entire market value" of the end product as the base is permissible only when the patent drives the demand for the end product. ${ }^{145}$ In yet more recent cases, however, the Federal Circuit has permitted use of the entire market value when the parties themselves negotiated ex ante on the basis of the entire accused

it invests the product with its own distinctive stamp (kennzeichnendes Gepräge). See Cotter 2013a, 268; Kühnen 2015, 700-02; Schönknecht 2012, 322-24. Similarly, in Japan courts typically use the value of the end product as the base. See Second Subcommittee of the Second Patent Committee 2014; Cotter 2015; Samsung Elecs. Co. v. Apple Japan LLC (IP High Ct. 2014) (Japan).

${ }^{144}$ Garretson v. Clark (U.S. 1884, p.121) (U.S.) (“The patentee . . . must in every case give evidence tending to separate or apportion the defendant's profits and the patentee's damages between the patented feature and the unpatented features.”).

145 See, e.g., VirnetX, Inc. v. Apple Inc. (Fed. Cir. 2014) (U.S.) (reversing a damages award based on the entire value of accused smartphone, rather than the smallest salable infringing component); LaserDynamics, Inc. v. Quanta Comp., Inc. (Fed. Cir. 2012, p.67) (U.S.) (“[I]t is generally required that royalties be based not on the entire product, but instead on the 'smallest salable patent-practicing unit.”). Though the term “entire market value rule” is generally now understood to have this meaning, earlier case law gave the doctrine much broader application. See Love 2007, 272(discussing older case law under which the entire market value rule acted as "a broad exception to the general rule of apportionment”). 
product, ${ }^{146}$ or comparable licenses were negotiated on the basis of entire products. ${ }^{147}$

In addition to concerns over apportionment, the Federal Circuit justifies its preference that the royalty base be the smallest saleable unit on the grounds that the value of the entire accused product will tend to have an undue influence on jurors in cases where the asserted patent covers just one of many components or features that comprise the entire product, and in such cases may lead to damages awards that are overcompensatory. ${ }^{148}$ The concern may stem from a cognitive bias known as “anchoring," i.e., the human tendency to give undue weight to the first data point one encounters, even if that data point is arbitrary or irrelevant. ${ }^{149}$ In the context of U.S. litigation,

${ }^{146}$ See CSIRO v. Cisco Sys., Inc. (Fed. Cir. 2015, p.1301-04) (U.S.) (holding that it was permissible for a court to consider evidence of the parties' previous negotiations, which were based on the entire value of the accused product).

${ }^{147}$ See Ericsson, Inc. v. D-Link Sys. (Fed. Cir. 2014, p.1225-29) (U.S.) (holding that it was permissible for a court to admit evidence of comparable licenses that were based on the entire value of allegedly infringing products). See also Teece \& Sherry 2016 (criticizing case law requiring litigants to use a smallest saleable unit royalty base on the grounds that "very few real-world licenses comport with the SSPPU doctrine, making it difficult to appeal to the terms of realworld licenses in assessing reasonable royalties.”).

${ }^{148}$ See VirnetX, Inc. v. Apple Inc. (Fed. Cir. 2014, p.1327) (U.S.) (noting that the “smallest saleable unit” requirement is based on a "fundamental concern about skewing the damages horizon" by "misleadingly suggest[ing] an inappropriate range” of damages); LaserDynamics, Inc. v. Quanta Comp., Inc. (Fed. Cir. 2012, p.68) (U.S.) (“Admission of . . . overall revenues, which have no demonstrated correlation to the value of the patented feature alone, only serve to make a patentee’s proffered damages amount appear modest by comparison, and to artificially inflate the jury's damages calculation beyond that which is 'adequate to compensate for the infringement.'”).

149 See, e.g., Furnham \& Boo 2011, 35(defining the “anchoring effect” as “the disproportionate influence on decision makers to make judgments that are biased toward an initially presented value.”). 
anchoring tends to reinforce the importance of the plaintiff's damages case, ${ }^{150}$ which is virtually always presented first and in some cases is not countered at all by the infringer. ${ }^{151}$ Experimental studies using fact patterns involving personal injury cases and punitive damages awards have found evidence of an anchoring effect and suggest that, all else equal, a plaintiff that requests more damages will tend to receive a larger award. ${ }^{152}$ Thus, there is a risk that reasonable royalty awards based on the entire value of the accused multi-component products will systematically overvalue patent rights that cover just a fraction of the products’ components or features.

A related problem is that, according to one study based on royalties awarded from 19822005, U.S. juries tend to award royalty rates that are within the general vicinity of 10 percent, regardless of the size of the base that the rate is applied to. ${ }^{153}$ Combined with anchoring, this

150 See Greene \& Bornstein 2003, 149-73 (reviewing the literature on anchoring's effect on juries). See also Posner \& Sunstein 2005, 593 (“Juries lack reference points, so their judgments will depend heavily on the presentation of evidence by lawyers, and on whatever anchors, prejudices, and expectations citizens bring to the jury box.”).

151 See Chao 2012, 136-37 (noting that the anchoring effect of the plaintiff's royalty base “is often exacerbated by the tactics defendants use at trial," including failure to offer a counter-anchor due to "fear that presenting a damages case will be interpreted as an admission of liability”).

152 See Campbell et al. 2016, 546 (finding in an experimental study of mock jurors deciding a medical malpractice case that "powerful anchoring effects dominate much smaller but still statistically significant credibility effects” that result from presenting “outrageous[ly]” large anchors); Chapman \& Bornstein 1996, 519 (finding in an experimental study of mock jurors deciding a personal injury case that "anchoring occurs in legal applications, and that plaintiffs would do well to request large compensation awards”); Hastie et al. 1999, 445 (finding in an experimental study in which mock jurors were asked to award punitive damages that "plaintiff's requested award values had a dramatic effect on awards: the higher the request, the higher the awards”).

153 See Lemley \& Shapiro 2007a, 2034 (finding in a study of 58 patent verdicts awarded between 1982 and 2005 that 
finding (if it is still valid) suggests that a patentee who is permitted to present large revenue figures to a jury or judge ${ }^{154}$ might receive a larger damages award as a result, even if the revenue figures themselves bear little relation to the value of the patented technology. On the other hand, we are not aware of any more recent studies on the issue, and it is possible that the effect has diminished over time (due, perhaps, to the abolition of the $25 \%$ Rule of Thumb). There is also concern that juries prefer whole-number rates even when the evidence suggests that the appropriate rate is less than $1 \%$. We therefore propose further research on the question of whether juries are susceptible to awarding inappropriately high damages given concerns with apportionment, anchoring, and preferences for particular royalty rates.

In addition, there may be a risk that use of the entire market value as the royalty base will skew litigation outcomes by encouraging patentees to sue downstream parties that are ill suited to defend patent cases. Imagine for example, an allegedly infringing component that is produced by manufacturer $\mathrm{M}$, incorporated into a consumer electronics product produced by company C, shipped to retailer R, and sold to user U. Because infringement can occur by making, selling, or

“[t]he royalty rate for components is approximately $10.0 \%$, compared with $13.1 \%$ for all inventions and $14.7 \%$ for integrated product claims”).

${ }^{154}$ Generally speaking, we think it is likely that judges, by virtue of their legal training and experience, will be less susceptible to this effect than lay jurors. As a result, this concern may be particularly acute in countries in which juries award damages, and less of a concern in countries where damages are calculated by judges. However, we do not believe that judges are completely immune. Indeed, experimental studies have shown that judges are susceptible to anchoring effects when awarding damages and determining criminal sentences. See Rachlinski et al. 2015, 695 (finding “that the presence of misleading numeric reference points (or 'anchors') affected judges' decisions in a series of hypothetical cases”). 
using patented technology, M, C, R, and U are all potential targets for suit. However, in all likelihood it is $\mathrm{M}$ that is best positioned to defend a patent suit. ${ }^{155} \mathrm{R}$ and $\mathrm{U}$, in particular, may well know nothing about how the component operates, not to mention the intricacies of patent law. Nonetheless, the effect of anchoring will tend to inflate the amount of damages a patentee can expect to recover from $\mathrm{C}, \mathrm{R}$, or $\mathrm{U}$. While $\mathrm{M}$ may sell the chip to $\mathrm{C}$ for pennies or a few dollars, $\mathrm{C}$ may earn dozens or hundreds of dollars per unit in sales to R, and R may sell the final product to users for several hundred dollars more per unit. ${ }^{156}$ In addition, $U$ may use the product as part of a business that generates many thousands of dollars a year. Given the option to choose, a patentee will find it advantageous (for reasons that have little to do with the value of the patented technology) to seek damages from component purchasers, retailers, or even users, all of whom have suboptimal incentives to test the patent's validity and the patentee's infringement contentions. ${ }^{157}$ On the other hand, if patentees are suing retailers and users who are ill-positioned

155 See Love \& Yoon 2013, 1620-35 (explaining that, compared to their downstream customers, manufacturers are less susceptible to litigation cost holdup and are better positioned to both test the merits of infringement allegations and appropriately value infringed patent rights). See also Europe Economics 2016, 5, 28, 48 (noting that European PAEs tend to target telecom companies, “the most vulnerable segment of the supply chain”).

${ }^{156}$ Consider, for example, an allegedly infringing \$6.50 3G wireless chipset installed in a smartphone that retails for \$500. See Love \& Yoon 2013, 1634 n.104 (using the example of a new iPhone 4S in 2013).

${ }^{157}$ Love \& Yoon 2013, 1628 (arguing that “[a]s between a similarly situated customer and manufacturer, it is virtually always the manufacturer that is best suited to vigorously litigate the case in a manner that challenges the patent's validity and delineates its claim scope” because customers are often "compan[ies] outside the technology industry that .... have no expertise in the accused technology[,] . . . . were not involved in the design, development, or manufacture of the accused technology[, and] ... . have no understanding of the field of the patent and no knowledge of the prior art to the patent”). Though it is true that a patentee will generally find it more costly to sue multiple downstream 
to defend themselves in an effort to obtain inappropriately high royalties, the first-best solution may be to rein in the ability to maintain patent infringement lawsuits down the chain of distribution, rather than to alter damages law.

Finally, limiting damages to the smallest saleable unit may have certain practical benefits. For example, defaulting to a smaller royalty base will tend to reduce the effect of error in royalty rate selection. ${ }^{158}$ It will also tend to narrow the range of possible trial outcomes, which benefits risk averse parties and increases the likelihood of pretrial settlement.

At the same time, there are several economic arguments in favor of using the entire market value as the royalty base. First, limiting damages calculations to the component level may undervalue patented technology by failing to share with the patentee a portion of the spillover

parties rather than a single manufacturer, experience suggests that many patentees will nonetheless make this choice. In the U.S., retailers are commonly sued for selling allegedly infringing products. For example, according to Lex Machina, Wal-Mart, Target, and Best Buy were each sued for patent infringement more than 80 times between 2012 and 2016. Moreover, some patentees have even pursued large numbers of end users of allegedly infringing products. Id. at 1610-11 (describing patent monetization campaigns undertaken by patentees like Innovatio IP Venutres, LLC, MPHJ Technology Investments, LLC, and ArrivalStar S.A., which collectively sued hundreds of end users and threatened to sue thousands more).

158 See Stern 2015, 554 n.26 (“[C]onsider a \$1 chip in a \$500 smartphone. Suppose the invention contributes $10 \%$ of the value of the chip and that the reasonable royalty is half of that or 5 cents, i.e., $5 \%$ of the $\$ 1$ chip price. In principle, the reasonable royalty based on the smartphone price would be the same 5 cents or $0.02 \%$ of $\$ 500$. But how is a jury or judge to determine the difference between a royalty of $0.02 \%$ and $0.01 \%$ or even $0.1 \%$ ? Yet the cash value of the error is multiplied greatly by starting out with an inflated royalty base. Choosing between infinitesimals is an inherently error-prone exercise.”). 
value created by its invention. ${ }^{159} \mathrm{~A}$ new high-resolution computer screen, for example, may be undervalued by U.S. patent law because, though demand for computers is not primarily driven by their screens, better screens enable or improve other computer functionality, such as video gaming and movie watching. ${ }^{160}$ While in many circumstances we would expect spillover value to be reflected in the sales price of the patented component, it may not be in some instances. Thus, as Petit has argued, "general purpose” technologies with many, relatively low-value uses may be undervalued in patent suits against parties that use the technology for less common applications that produce especially large cost savings or profits. ${ }^{161}$

Relatedly, to the extent price discrimination is economically efficient, it makes sense to allow patent owners to extract a higher royalty from implementers who market comparatively

159 See Petit 2016 (arguing that use of a “smallest saleable unit” benchmark for patent damages may undervalue “general purpose technologies” that “yield countless positive production externalities”); Geradin \& Layne-Farrar 2010, 774-76 (arguing that a strict application of the U.S. entire market value rule may undervalue patent rights to a component of a complex product "if the component in question 'enables' other components but does not rise to the level of driving demand”).

160 See Geradin \& Layne-Farrar 2010, 775 (using this same example).

161 See Petit 2016 (using the example of wireless technology that, when adopted for use in airplanes, led to substantial cost savings by reducing aircraft weight and, consequently, fuel costs). See also Régibeau et al. 2016,77 comparing wireless technology in a smartphone, which “do[es] appear to influence a number of important functionalities,” to wireless technology in a car, which "it would be rash to argue . . contribute to a very substantial share of the value that consumers place on specific cars”); Layne-Farrar 2017 (recommending that courts focus on valuing the use of a technology to the implementer, not on trying to pinpoint its location in a particular component; and that they should permit experts to use as the royalty base the implementer's properly apportioned revenue, without disclosing to the jury the infringer's overall revenues or profits). 
expensive end products for which the patent confers substantial value. In addition, as noted above, in real-world licensing transactions parties often, though not invariably, use the entire market value as the base. To the extent reasonable royalty awards should mimic real-world licenses, use of the entire market value often would seem unexceptional. ${ }^{162}$

Given the wide variety of arguments for and against the entire market value/SSPPU rules as employed in the United States, we first propose further research, both with regard to the economic issues highlighted above and into the psychology of judges and juries (e.g., can anchoring and other biases be overcome in other ways?). Given the likelihood that anchoring does play a role in jury deliberations, however, we further recommend that, for now at least, the Federal Circuit retain rules substantially restricting the use of the entire market value. By the same token, given the likelihood that professional judges are less affected (though perhaps not unaffected) by anchoring, for now we do not recommend that other countries (which do not employ juries to decide patent cases) alter their more liberal approach to the use of the entire market value.

\section{Practical Considerations}

In this final Part, we briefly address three remaining practical issues that courts in some countries either have considered or may devote further attention to in the future, namely (1) the evaluation of individual pieces of expert evidence to satisfy a basic threshold of quality; (2) the enhancement of reasonable royalty awards to achieve additional deterrence; and (3) the calibration

\footnotetext{
162 See also Baron \& Pentheroudakis 2017, 93-94 (noting that “[t]he practicability (and traceability) of the SSPPU is questionable in the context of portfolio licensing: it is often not possible to map a portfolio of hundreds or even thousands of diverse patents to a single SSPPU”).
} 
of damages awards based on context-specific factors.

\section{A. Expert Evidence and Daubert Gatekeeping in the United States}

In the United States, there are two main ways by which judges can police proof of reasonable royalty damages. First, they can enforce and, as appropriate and necessary, develop legal doctrine directly regulating what constitutes adequate evidence for reasonable royalty damages. Second, they can enforce and, as appropriate and necessary, develop legal doctrine regulating the admissibility of evidence for purposes of such proof.

The second, admissibility-oriented mechanism looms large in the United States, where the primary fact-finder is commonly a jury, rather than the trial judge. Under the United States' Federal Rule of Evidence 702, which essentially embodies a requirement previously articulated by the Supreme Court of the United States in Daubert v. Merrell Dow Pharmaceuticals, Inc., ${ }^{163}$ trial judges police the admissibility of expert testimony to ensure that this evidence "will help the trier of fact to understand the evidence or to determine a fact in issue," "is based on sufficient facts or data," and results from the application of "reliable principles and methods." ${ }^{64}$ Because expert testimony is often a vital component of the proof of reasonable royalty damages, judicial gatekeeping under Daubert has become a powerful tool for limiting the permissible evidentiary bases for such damages. The U.S. Court of Appeals for the Federal Circuit has reversed or vacated

\footnotetext{
${ }^{163}$ Daubert v. Merrell Dow Pharm. Inc. (U.S. 1993) (U.S.); see also Bernstein \& Lasker 2015, 6 ("In 2000, the Judicial Conference of the United States ... amended Federal Rule of Evidence 702 for the express purpose of resolving conflicts in the courts about the meaning of Daubert.”).

${ }^{164}$ FED. R. EVID. 702.
} 
a number of damages verdicts in patent cases on Daubert grounds. ${ }^{165}$

In the absence of a jury or other fact-finder distinct from the trial-level adjudicator of questions of law, there is probably less significance to the distinction between (1) the ultimate assessment of the overall sufficiency of evidence to support a damages award and (2) gatekeeping for the relevance and reliability of expert testimony. But although the particular standard for expert testimony gatekeeping has been controversial within the United States, ${ }^{166}$ something like Daubertstyle review might generally be useful even in the absence of juries. We recommend that courts consider whether individual pieces of expert evidence satisfy a basic threshold of quality in addition to separately examining the overall sufficiency of all relevant evidence.

\section{B. “Kickers” for Reasonable Royalties}

There has been discussion in the United States about whether there should be the possibility of a "kicker" that increases damages beyond a straight reasonable royalty for any of multiple

165 See, e.g., VirnetX, Inc. v. Apple Inc. (Fed. Cir. 2014, p.1329, 1333-34) (U.S.) (holding that damages expert’s testimony on the royalty base and in support of a fifty-fifty split of profits was inadmissible); LaserDynamics, Inc. v. Quanta Comp., Inc. (Fed. Cir. 2012, p.79) (U.S.) (holding that a damages expert's testimony on the value of a reasonable royalty rate "was unreliable under Federal Rule of Evidence 702 and should have been excluded”); Uniloc USA, Inc. v. Microsoft Corp. (Fed. Cir. 2011, p.1318) (U.S.) (affirming grant of a new trial on damages where expert testimony based on a "25\% rule of thumb" for the proportion of product value constituting a reasonable royalty "fail[ed] to pass muster under Daubert").

166 See, e.g., Bernstein \& Lasker 2015, 9 (reporting “continued divisions among federal courts over the proper standards for admission of expert testimony . . . .); Faigman \& Imwinkelreid 2013, 1695 (“Even if Daubert is the right choice for the federal judiciary, a state could reasonably conclude that it is not the right path for it to take.”). 
reasons: for example, compensation for litigation costs, ${ }^{167}$ deterrence, ${ }^{168}$ compensation for lost profits that a royalty rate might not ordinarily reflect, ${ }^{169}$ and correction for pre-existing royalty rates’ incorporation of a discount because of uncertainty about patent claim validity or scope. ${ }^{170}$ The U.S. Court of Appeals for the Federal Circuit has indicated that courts may combine a reasonable royalty award with compensation for other damages that the royalty does not coverfor example, lost profits from depression of royalties obtained from others because infringement has bred "widespread and open disregard of [relevant] patent rights." ${ }^{171}$ But the Federal Circuit has also held that monetary awards to compensate for litigation expenses or to punish an infringer may only be awarded in accordance with statutory provisions and precedent specific to awards of

167 Cotter 2004, 316 (noting a "Federal Circuit decision stating that courts may not incorporate into the reasonable royalty award a damages 'kicker’ so as to compensate the patentee for litigation and other expenses”).

${ }^{168} I d$. (indicating that a damages "kicker” might advance goals of deterrence).

169 Lee \& Melamed 2016, 459 (“[S]ince the royalty may include a 'kicker’ based on Georgia-Pacific Factor 4 (the patent holder's policy of licensing or not licensing the patent), patent holders are generally compensated at least to some extent for their loss of market exclusivity.”); Yang 2014, 655 (noting scholarly speculation that “[c]ourts, worried about undercompensating patentees who could not prove lost profits, added 'kickers' to reasonable royalty awards ....”).

170 Lemley \& Shapiro 2007a, 2019-20 (contending that “[c]ourts have recognized [the discount] problem and periodically seek to modify the market-based royalty data by adding 'kickers,' either expressly or sub rosa.”); see also supra note 15 (noting the occasional practice in France and Germany of increasing royalties to account for risks the infringer has avoided).

${ }^{171}$ Maxwell v. J. Baker, Inc. (Fed. Cir. 1996, p.1109) (U.S.) (quoting jury instruction). 
attorney fees or enhanced damages. ${ }^{172}$ Thus, under current law in the United States, courts may not include a kicker for such purposes when assessing standard compensatory damages.

Consideration of awarding a kicker beyond reasonable royalties generally seems best addressed under other rubrics, which we explore in other parts of this book. In this chapter, we have already addressed questions about the need to correct for pre-litigation uncertainty in the context of the hypothetical negotiation framework. Likewise, questions about when and how to award lost profits are addressed in Chapter 2, and questions about when and how to punish infringement or compensate for litigation costs are discussed in Chapter 3. Rather than handle such concerns obliquely through the use of kickers added to reasonable royalties, we recommend that they be addressed directly through remedial doctrines created for those particular purposes.

\section{Calibrated Evidentiary Burdens or Royalty Measures}

As an alternative to applying the same standards for measuring or proving reasonable royalty damages in every case, courts could apply standards for measuring or proving reasonable royalty damages that are responsive to context-specific factors. These factors could include (1) the relative blameworthiness of the parties; "(2) the state of the art or the availability of evidence for proving damages,” including one or another party's status as a cheaper information provider; and “(3) the amount of damages alleged." ${ }^{173}$ Calibration of damages measures or evidentiary burdens

172 Whitserve, LLC v. Computer Packages, Inc. (Fed. Cir. 2012, p.34 n.18) (U.S.).

173 Golden 2017, 274; see also Chiang 2017 (advocating two principles for the assignment of evidentiary burdens in damages law: (1) "courts should only require a party to produce information when the social benefit of the information ... exceeds the costs of producing the information” and (2) “courts should impose the burden of proof on the party 
based on context-specific factors has occurred in other legal areas, such as contract law ${ }^{174}$ and the law of restitution. ${ }^{175}$ In these areas of law, doubts are often resolved against parties viewed as blameworthy, ${ }^{176}$ and courts have relaxed "demands of reasonable certainty when ... the state of

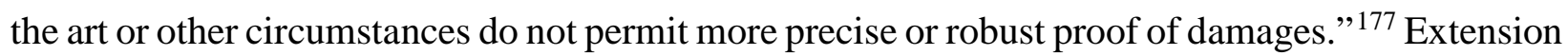
of such calibration to encompass sensitivity to "the amount of damages alleged" seems plausible and perhaps even natural for a form of monetary relief that uses the word "reasonable" in its very name. At least if the law wishes to ensure that smaller claims for damages are practically enforceable, the law should not generally demand that a claimant for such limited damages expend more on proving these damages than the claimant alleges the damages to be worth. Nonetheless, because there is enough immediate challenge in articulating basic principles for computing reasonable royalties, we propose further research on more context-specific calibration.

that can produce the required evidence at lower cost.”).

${ }^{174}$ Golden 2017, 272 (observing that, in contract law, “courts have allowed for pragmatic or fairness-oriented tuning of certainty standards on a retail as well as a wholesale basis.”).

${ }^{175}$ Golden \& Sandrik 2017 ("The law of restitution illustrates how, in addressing difficult-to-quantify monetary relief, courts can develop a context-sensitive yet coherent approach that ... deploys both [monetary-relief] measures and burdens of proof or production in ways that distinguish between levels of relative responsibility or fault.”).

${ }^{176}$ See Golden 2017, 271 (discussing treatments of doubts and blameworthiness in the First and Second Restatements of Contracts); Golden \& Sandrik 2017 (discussing how the Restatement (Third) of Restitution and Unjust Enrichment assigns evidentiary burdens in accordance with " the equitable disposition that resolves uncertainty in favor of the claimant against the conscious wrongdoer”' (quoting Restatement (Third) of Restitution and Unjust Enrichment § 51 cmt. i)).

177 Golden 2017, 272. 


\section{BIBLIOGRAPHY}

Cases:

Canada:

AlliedSignal Inc. v. DuPont Canada Inc., [1998] 78 CPR(3d) 129 (Fed. Ct.)

Jay-Lor Int’l Inc. v. Penta Farm Sys. Ltd., [2007] FC 358 (Fed. Ct.)

\section{Germany:}

Bundesgerichtshof v. 14.3.2000 - X ZR 115/98 - GRUR 2000, 685 = NJW 2001, 1332

Bundesgerichtshof v. 6.3.1980 - X ZR 49/78 - Tolbutamid, GRUR 1980, 841 = NJW 1980, 2522

Japan: 
Fulta Elec. Machinery Co. v. Watanabe Kikai Kogyo K. K., Chiteki Zaisan Kōtō Saibansho [Intellectual Prop. High. Ct., Fourth Division] Nov. 12, 2015, Hei 27 (ne) No. 10048, CHITEKI

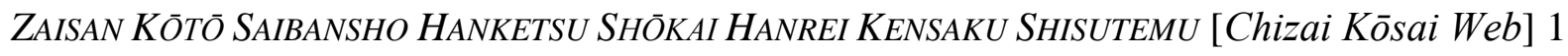
http://www.ip.courts.go.jp/app/files/hanrei_en/923/001923.pdf

Samsung Elecs. Co. v. Apple Japan LLC, Chiteki Zaisan Kōtō Saibansho [Intellectual Prop.

High. Ct., Special Division] May 16, 2014, Hei 25 (ne) No. 10043, СнITEKI ZAISAN Кōtō SAIBANSHO HANKETSU SHŌKAI HANREI KeNSAKU SHISUTEMU [Chizai Kōsai Web] 1 (FRAND I) http//www.ip.courts.go.jp/eng/vcms_lf/25ne10043full.pdf

\section{United Kingdom:}

General Tire \& Rubber Co. Ltd. v. Firestone Tyre \& Rubber Co. Ltd., [1975] 2 All ER 173 (HL)

Unwired Planet Int’l Ltd. v. Huawei Techs. Co., [2017] EWHC 711 (Pat)

\section{United States:}

Apple, Inc. v. Motorola, Inc., 869 F.Supp.2d 901 (N.D. Ill. 2012) 
Apple, Inc. v. Motorola, Inc., 757 F.3d 1286 (Fed. Cir. 2014)

Carson et al. v. American Smelting \& Refining Co., 25 F.2d 116 (W.D. Wash. 1928)

Cincinnati Car Co. v. New York Rapid Transit Corp., 66 F.2d 592 (2d Cir. 1933)

Commonwealth Sci. and Indus. Research Org. (CSIRO) v. Cisco Sys., Inc., 809 F.3d 1295 (Fed. Cir. 2015)

Consol. Rubber Tire Co. v. Diamond Rubber Co. of NY, 226 F. 455 (S.D.N.Y. 1915)

Daubert v. Merrell Dow Pharm. Inc., 509 U.S. 579 (1993)

Dowagiac Mfg. Co. v. Minn. Moline Plow Co., 235 U.S. 641 (1915)

Ericsson, Inc. v. D-Link Sys., 773 F.3d 1201 (Fed. Cir. 2014)

Fromson v. W. Litho Plate \& Supply Co., 853 F.2d 1568 (Fed. Cir. 1988) overruled by KnorrBremse Systeme Fuer Nutzfahrzeuge GmbH v. Dana Corp., 383 F.3d 1337 (Fed. Cir. 2004) 
Garretson v. Clark, 111 U.S. 120 (1884)

Georgia-Pacific Corp. v. U.S. Plywood Corp., 318 F. Supp. 1116 (S.D.N.Y. 1970)

Georgia-Pacific Corp. v. U.S. Plywood Corp., 446 F.2d 295 (2d Cir. 1971)

Grain Processing Corp. v. Am. Maize-Prods. Co., 185 F.3d 1341 (Fed. Cir. 1999)

Hanson v. Alpine Valley Ski Area, Inc., 718 F.2d 1075 (Fed. Cir. 1983)

In re Innovatio IP Ventures, LLC Patent Litigation, Case No. 11 C 9308, 2013 WL 5593609

(N.D. Ill. 2013)

LaserDynamics, Inc. v. Quanta Comp., Inc., 694 F.3d 51 (Fed. Cir. 2012)

Lucent Techs., Inc. v. Gateway, Inc., 580 F.3d 1301 (Fed. Cir. 2009)

Maxwell v. J. Baker, Inc., 86 F.3d 1098 (Fed. Cir. 1996) 
Microsoft Corp. v. Motorola, Inc., Case No. C10-1823JLR, 2013 WL 2111217 (W.D. Wash. 2013)

Monsanto Co. v. E.I. DuPont De Nemours \& Co., Case No. 4:09-CV-00686-ERW, 2013 WL 10300977 (E.D. Mo. 2013)

Nickson Indus., Inc. v. Rol Mfg. Co., 847 F.2d 795 (Fed. Cir. 1988)

Panduit Corp. v. Stahlin Bros. Fibre Works Inc., 575 F.2d 1152 (6th Cir. 1978)

Prism Techs. LLC v. Sprint Spectrum L.P., 849 F.3d 1360 (Fed. Cir. 2017)

ResQNet.com, Inc. v. Lansa, Inc., 594 F.3d 860 (Fed. Cir. 2010)

Rite-Hite Corp. v. Kelley Co., 56 F.3d 1538 (Fed. Cir. 1995) (en banc)

Rude v. Westcott, 130 U.S. 152 (1889) 
Sinclair Ref. Co. v. Jenkins Petroleum Process Co., 289 U.S. 689 (1933)

St. Lawrence Comm’ns LLC v. ZTE Corp., Case No. 2:15-cv-349-JRG, 2017 WL 679623 (E.D. Tex. 2017)

Summit 6, LLC v. Samsung Electronics Co., 802 F.3d 1283 (Fed. Cir. 2015)

TCL Commc’ns Tech. Holdings, Ltd. v. Telefonaktiebolaget LM Ericsson, Case No. SACV 14341 JVS (DFMx), 2017 WL 6611635 (C.D. Cal. 2017)

Tights, Inc. v. Kayser-Roth Corp., 442 F. Supp. 159 (M.D.N.C. 1977)

TWM Mfg. Co., Inc. v. Dura Corp., 789 F.2d 895 (Fed. Cir. 1986), cert. denied 479 U.S. 852 (1986)

Uniloc USA, Inc. v. Microsoft Corp., 632 F.3d 1292 (Fed. Cir. 2011)

U.S. Frumentum Co. v. Lauhoff, 216 F. 610 (6th Cir. 1914) 
VirnetX, Inc. v. Apple Inc., 767 F.3d 1308 (Fed. Cir. 2014)

Whitserve, LLC v. Computer Packages, Inc., 694 F.3d 10 (Fed. Cir. 2012)

$\underline{\text { Regulatory and Legislative Materials: }}$

\section{United States:}

Patent Reform Act of 2009: Hearing on H.R. 1260 Before the H. Comm. on the Judiciary, 111th Cong. 75 (2009) (prepared statement of Professor John R. Thomas, Georgetown University Law School)

The Evolving IP Marketplace: Hearing before the Fed. Trade Comm'n, Matter No. P093900, 15 (Feb. 11, 2009) (testimony of Professor Paul M. Janicke, University of Houston Law Center).

U.S. Patent Act, 35 U.S.C. § 284 
Books, Articles and Online Materials:

American Intellectual Property Law Association (AIPLA). 2015. 2015 Report of the Economic Survey, Arlington V.A.: American Intellectual Property Law Association.

American Law Institute (ALI). 2011. Restatement (Third) of Restitution and Unjust Enrichment.

Bernstein, David E. \& Eric G. Lasker. 2015. “Defending Daubert: It’s Time to Amend Federal Rule of Evidence,” William \& Mary Law Review 57(1): 1-48.

Berry, Chris, Ronen Arad, Landan Ansell, Meredith Cartier \& HyeYun Lee. 2017. 2017 Patent Litigation Study: Change on the Horizon?, PricewaterhouseCoopers. https://www.pwc.com/us/en/forensic-services/publications/assets/2017-patent-litigationstudy.pdf

Blair, Roger D. \& Thomas F. Cotter. 2005. Intellectual Property: Economic and Legal Dimensions of Rights and Remedies, New York, N.Y.: Cambridge University Press.

Byrd, Owen, Brian C. Howard \& Jason Maples. 2014. 2014 Lex Machina Patent Litigation Damages Report, Menlo Park, CA: Lex Machina. 
Camesasca, Peter, Gregor Langus, Damien Neven \& Pat Treacy. 2013. “Injunctions for Standard-Essential Patents: Justice Is Not Blind,” Journal of Competition Law \& Economics 9(2): 285-311.

Campbell, John E., Bernard Chao, Christopher T. Roberson \& David V. Yokum. 2016.

“Countering the Plaintiff's Anchor: Jury Simulations to Evaluate Damages Arguments,” Iowa Law Review 101(2): 543-71.

Carlton, Dennis W. \& Allan L. Shampine. 2013. “An Economic Interpretation of FRAND,” Journal of Competition Law \& Economics 9(3): 531-52.

Chao, Bernard \& Jonathan Gray. 2013. “A \$1 Billion Parable,” Denver University Law Review 90: 185-91.

Chao, Bernard. 2012. “The Case for Contribution in Patent Law,” University of Cincinnati Law Review 80(1): 113-59.

Chapman, Gretchen B. \& Brian H. Bornstein. 1996. “The More You Ask For, the More You Get: Anchoring in Personal Injury Verdicts,” Applied Cognitive Psychology 10(6): 519-40. 
Chiang, Tun-Jen. 2017. “The Information-Forcing Dilemma in Damages Law,” William \& Mary Law Review 59(1): 81-145.

Chien, Colleen V., Thomas F. Cotter \& Richard A. Posner. (Forthcoming). Redesigning Patent Law, (unpublished manuscript on file with authors).

Choi, Jay Pil. 2009. “Alternative Damage Rules and Probabilistic Intellectual Property Rights: Unjust Enrichment, Lost Profits, and Reasonable Royalty Remedies,” Information Economics \& Policy 21(2): 145-57.

Contreras, Jorge L. \& Michael A. Eixenberger. 2016. “Model Jury Instructions for Reasonable Royalty Patent Damages,” Jurimetrics 57(1): 1-24.

Contreras, Jorge L. \& Richard J. Gilbert. 2015. “A Unified Framework for RAND and Other Reasonable Royalties,” Berkeley Technology Law Journal 30: 1451-1504.

Contreras, Jorge L., Colleen Chien, Thomas F. Cotter \& Brad Biddle. 2016. “Study Proposal — Commercial Patent Licensing Data.” https://papers.ssrn.com/abstract_id=2755706

Cotter, Thomas F. \& John M. Golden. 2018. “Empirical Studies Relating to Patents: Remedies,” 
in Peter S. Menell and David L. Schwartz, eds., Research Handbook on the Economics of Intellectual Property Law: Analytical Methods, Cheltenham: Edward Elgar, https://papers.ssrn.com/sol3/papers.cfm?abstract_id=2665680 (forthcoming).

Cotter, Thomas F. 2004. “An Economic Analysis of Enhanced Damages and Attorney’s Fees for Willful Patent Infringement,” Federal Circuit Bar Journal 14: 291-331.

--- 2011. “Four Principles for Calculating Reasonable Royalties in Patent Infringement Litigation,” Santa Clara Computer and High Technology Law Journal 27(4): 725-61.

--- 2013a. Comparative Patent Remedies: A Legal and Economic Analysis, New York, N.Y.: Oxford University Press.

--- 2013b. "Reining in Remedies in Patent Litigation: Three (Increasingly Immodest) Proposals," Santa Clara High Tech Law Journal 30: 1-30.

--- 2014a. “Comparative Law and Economics of Standard-essential Patents and FRAND Royalties,” Texas Intellectual Property Law Journal 22: 311-63.

--- 2015. “A Study of Reasonable Royalty Awards in Japan,” Comparative Patent 
Remedies, Mar. 23, 2015. https://comparativepatentremedies.blogspot.com/2015/03/a-study-of$\underline{\text { reasonable-royalty-awards-in.html }}$

--- 2018. “Patent Damages Heuristics,” Texas Intellectual Property Law Journal 25(2): 159-213.

Cox, Alan. 2017. “The Limited Role of Analytical Approach to Reasonable Royalty,” Law360, Apr. 13, 2017.

Denicolò, Vincenzo, Damien Geradin, Anne Layne-Farrar \& A. Jorge Padilla. 2008. "Revisiting Injunctive Relief: Interpreting eBay in High-Tech Industries with Non-Practicing Patent Holders,” Journal of Competition Law \& Economics 4(3): 571-608.

Dumont, Béatrice. 2015. “Does Patent Quality Drive Damages in Patent Lawsuits? Lessons from the French Judicial System,” Review of Law \& Economics 11(2): 355-383.

Durie, Daralyn J. \& Mark A. Lemley. 2010. “A Structured Approach to Calculating Reasonable Royalties,” Lewis \& Clark Law Review 14: 627-50.

Elhauge, Einer. 2008. “Do Patent Holdup and Royalty Stacking Lead to Systematically 
Excessive Royalties?,” Journal of Competition Law \& Economics 4(3): 535-570.

Elmer, Michael C. \& C. Gregory Gramenopoulos. 2016. Global Patent Litigation: How and Where to Win, Second Edition, Arlington V.A.: Bloomberg BNA.

Epstein, Roy J. \& Alan J. Marcus. 2003. “Economic Analysis of the Reasonable Royalty: Simplification and Extension of the Georgia-Pacific Factors,” Journal of the Patent and Trademark Office Society 85(7): 555-81.

Europe Economics. 2016. JRC Science for Policy Report: Patent Assertion Entities in Europe: Their Impact on Innovation and Knowledge Transfer in ICT Markets (Nikolaus Thumm \& Garry Gabison eds.), Luxembourg: Publications Office of the European Union. http://publications.jrc.ec.europa.eu/repository/bitstream/JRC103321/lfna28145enn.pdf

Faigman, David L. \& Edward J. Imwinkelreid. 2013. "Wading into the Daubert Tide: Sargon Enterprises, Inc. v. University of Southern California,” Hastings Law Journal 64(6): 1665-96.

Farrell, Joseph, John Hayes, Carl Shapiro \& Theresa Sullivan. 2007. "Standard Setting, Patents, and Hold-Up,” Antitrust Law Journal 74: 603-70. 
Federal Circuit Bar Association (FCBA). 2016. “Model Patent Jury Instructions.”

https://fedcirbar.org/IntegralSource/Model-Patent-Jury-Instructions

Frischmann, Brett M. \& Mark A. Lemley. 2007. “Spillovers,” Columbia Law Review 107: 257301.

Furnham, Adrian \& Hua Chu Boo. 2011. “A Literature Review of the Anchoring Effect,” The Journal of Socio-Economics 40(1): 35-42.

Geradin, Damien \& Anne Layne-Farrar. 2010. “Patent Value Apportionment Rules for Complex Multi-Patent Products,” Santa Clara High Technology Law Journal 27(4): 763-92.

Gilbert, Richard J. 2011. “Deal or No Deal? Licensing Negotiations in Standard-Setting Organizations,” Antitrust Law Journal 77: 855-88.

Golden, John M. \& Karen E. Sandrik. 2017. “A Restitution Perspective on Reasonable Royalties,” The Review of Litigation 36(2): 335-77.

Golden, John M. 2010. “Principles for Patent Remedies,” Texas Law Review 88(3): 505-92. 
--- 2017. “Reasonable Certainty in Contract and Patent Damages,” Harvard Journal of Law \& Technology 30: 257-78.

Goldscheider, Robert, John Jarosz \& Carla Mulhern. 2002. “Use of The 25 Per Cent Rule In Valuing IP,” les Nouvelles 37: 123-133.

Gooding, Martha K. 2012. “Analyzing the 'Analytic Method’ of Calculating Reasonable Royalty Patent Damages,” Patent, Trademark \& Copyright Law Daily (Bloomberg BNA), May 14, 2012.

Greene, Edie \& Brian H. Bornstein. 2003. Determining Damages: The Psychology of Jury Awards, Washington, D.C.: American Psychological Association.

Hastie, Reid, David A. Schkade \& John W. Payne. 1999. “Juror Judgments in Civil Cases: Effects of Plaintiff's Requests and Plaintiff's Identity on Punitive Damage Awards,” Law \& Human Behavior 23(4): 445-70.

Heath, Christopher. 2015. Patent Enforcement Worldwide: Writings in Honour of Dieter Stauder, Third Edition, Portland, O.R.: Hart Publishing.

Henrich, Joseph. 2015. The Secret of Our Success: How Culture Is Driving Human Evolution, 
Domesticating Our Species, and Making Us Smarter, Princeton, N.J.: Princeton University Press.

Howard, Brian C. \& Jason Maples. 2017. “Lex Machina Patent Litigation Year in Review 2016,” Menlo Park, CA: Lex Machina.

Hovenkamp, Erik \& Jonathan S. Masur. 2017. "How Patent Damages Skew Licensing Markets,” The Review of Litigation 36(2): 379-416.

Janicke, Paul M. 1993. “Contemporary Issues in Patent Damages,” American University Law Review 42: 691-736.

Jarosz, John C. \& Michael J. Chapman. 2013. “The Hypothetical Negotiation and Reasonable Royalty Damages: The Tail Wagging the Dog,” Stanford Technology Law Review 16: 769-830.

Kühnen, Thomas. 2015. Patent Litigation Proceedings in Germany: A Handbook for Practitioners, Cologne, Ger.: Carl Heymanns Verlag.

Layne-Farrar, Anne, Gerard Llobet \& A. Jorge Padilla. 2009. "Preventing Patent Holdup: An Economic Assessment of Ex Ante Licensing Negotiations in Standard Setting,” AIPLA Quarterly Journal 37(4): 445-78. 
Layne-Farrar, Anne. 2014. "Moving Past the SEP RAND Obsession: Some Thoughts on the Economic Implications of Unilateral Commitments and the Complexities of Patent Licensing,” George Mason Law Review 21: 1093-1110.

--- 2017. “The Patent Damages Gap: An Economist's Review of U.S. Patent Damages Apportionment Rules,” Working Paper (Apr. 8, 2017).

http://papers.ssrn.com/abstract_id=2911289

Lee, William F. \& A. Douglas Melamed. 2016. “Breaking the Vicious Cycle of Patent Damages,” Cornell Law Review 101: 385-466.

Lemley, Mark A. \& Carl Shapiro. 2007a. "Patent Holdup and Royalty Stacking,” Texas Law Review 85(7): 1991-2049.

Lemley, Mark A. 2005. “Property, Intellectual Property, and Free Riding,” Texas Law Review 83: 1031-75.

Love, Brian J. \& James C. Yoon. 2013. “Expanding Patent Law’s Customer Suit Exception,” Boston University Law Review 93(5): 1605-41. 
Love, Brian J. 2007. “Patentee Overcompensation and the Entire Market Value Rule,” Stanford Law Review 60(1): 263-294.

Masur, Jonathan S. 2015. “The Use and Misuse of Patent Licenses,” Northwestern University Law Review 110: 115-57.

Matsunaka, Masahiko. 2004. "FY 2003 Study Report on the Japanese Economic Structure from a Competition Policy Perspective_-Court Judgments Concerning Calculation of the Amount of Damages in Intellectual Property Infringement Litigation,” Institute of Intellectual Property Bulletin 13: 168-177.

McGowan, David. 2010. “Irreparable Harm,” Lewis \& Clark Law Review 14: 577-596.

Mueller, Christopher B. \& Laird C. Kirkpatrick. 1999. “§ 3.5 —Underlying Reasons and Examples,” Evidence, New York, N.Y.: Aspen Law \& Business.

Nakamura, Nodoka. 2014. "Recent Trends in Court Judgments Concerning Damages in Japanese Patent Infringement Litigations,” A.I.P.P.I.—Japan 39: 389-410. 
Narechania, Tejas N. \& Jackson Taylor Kirklin. 2012. “An Unsettling Development: The Use of Settlement-Related Evidence for Damages Determinations in Patent Litigation," University of Illinois Journal of Law, Technology \& Policy 2012(1): 1-44.

Page, William H. 2014. “Judging Monopolistic Pricing: F/RAND and Antitrust Injury,” Texas Intellectual Property Law Journal 22: 181-208.

Pedigo, Mark. 2017. “Determining Reasonable Royalties with Analytical Approach,” Law360, Mar. 3, 2017.

Pentheroudakis, Chryssoula \& Justus A. Baron. 2017. JRC Science for Policy Report: Licensing Terms of Standard Essential Patents: A Comprehensive Analysis of Cases (Nikolaus Thumm ed.), Luxembourg: Publications Office of the European Union. http://publications.jrc.ec.europa.eu/repository/bitstream/JRC104068/jrc104068\%20online.pdf

Petit, Nicolas. 2016. "The Smallest Saleable Patent-Practicing Unit (SSPU) Experiment: General Purpose Technologies and the Coase Theorem,” Working Paper (Feb. 18, 2016). https://papers.ssrn.com/sol3/papers.cfm?abstract_id=2734245

Platt, S. Christian \& Bob Chen. 2013. "Recent Trends and Approaches in Calculating Patent Damages: Nash Bargaining Solution and Conjoint Surveys," Patent, Trademark \& Copyright 
Law Daily (Bloomberg BNA), Aug. 30, 2013.

Posner, Eric A. \& Cass R. Sunstein. 2005. “Dollars and Death,” University of Chicago Law Review 72(2): 537-98.

Posner, Richard A. 1999. “An Economic Approach to the Law of Evidence,” Stanford Law Review 51: 1477-1546.

Rachlinski, Jeffery J., Andrew J. Wistrich \& Chris Guthrie. 2015. “Can Judges Make Reliable Numeric Judgments? Distorted Damages and Skewed Sentences,” Indiana Law Journal 90(2): 695-739.

Régibeau, Pierre, Raphaël De Coninck \& Hanz Zengler. 2016. Transparency, Predictability, and Efficiency of SSO-based Standardization and SEP Licensing: A Report for the European Commission, European Union.

République Française, Ministère du Redressement Productifs. 2014. “Étude Comparée sur les Dommages et Intérêts Alloués dans le Cadre des Actions en Contrefaçon en France, Au Royaume-Uni et en Allemagne.” 
Risch, Michael. 2018. “(Un)reasonable Royalties,” Boston University Law Review 98(1): 187261.

Rooklidge, William. 2014. "Infringer's Profits Redux: The Analytical Method of Determining Patent Infringement Reasonable Royalty Damages,” Patent, Trademark \& Copyright Law Daily (Bloomberg BNA), Nov. 5, 2014.

Rubinstein, Ariel. 1982. "Perfect Equilibrium in a Bargaining Model,” Econometrica 50(1): 97109.

Schlicher, John W. 2009. "Patent Damages, the Patent Reform Act, and Better Alternatives for the Courts and Congress,” Journal of the Patent and Trademark Office Society 91: 21-76.

Schönknecht, Markus. 2012. "Determination of Patent Damages in Germany,” International Review of Intellectual Property \& Competition Law 43(3): 309-332.

Seaman, Christopher B. 2010. "Reconsidering the Georgia-Pacific Standard for Reasonable Royalty Patent Damages,” Brigham Young University Law Review 2010(5): 1661-1727.

Second Subcommittee of the Second Patent Committee. 2014. "Predictability of Monetary 
Damages under Article 102(3) of the Japanese Patent Law," Intellectual Property Management 64: 219-235 (in Japanese).

Sedona Conference. 2014. “Commentary on Patent Damages and Remedies: A Project of the Sedona Conference Working Group on Patent Damages and Remedies (WG9), Public Comment Version.” https://thesedonaconference.org/download-pub/3827

--- 2016. “Commentary on Patent Reasonable Royalty Determinations: A Project of The Sedona Conference Working Group on Patent Damages and Remedies (WG9), December 2016 Edition.”

https://thesedonaconference.org/system/files/sites/sedona.civicactions.net/files/private/drupal/file sys/publications/Sedona\%20WG9\%20Patent\%20Reasonable\%20Royalty\%20Determinations\%2 0\%28Dec.\%202016\%20ed\%29_12-15-16.pdf

Shapiro, Carl. 2010. "Injunctions, Hold-Up, and Patent Royalties,” American Law \& Economics Review 12(2): 280-318.

Sidak, J. Gregory \& Jeremy O. Skog. 2016. “Using Conjoint Analysis to Apportion Patent Damages,” Federal Circuit Bar Journal 25: 581-620.

Sidak, J. Gregory. 2016a. “Apportionment, FRAND Royalties, and Comparable Licenses After 
Ericsson v. D-Link,” University of Illinois Law Review 2016(4): 1809-70.

Siebrasse, Norman V. \& Thomas F. Cotter. 2016. “A New Framework for Determining Reasonable Royalties in Patent Litigation,” Florida Law Review 68(4), 929-999.

--- 2017a. “The Value of the Standard,” Minnesota Law Review 101(3): 1159-1246.

Skenyon, John M., Christopher Marchese, John Land \& Frank Porcelli. 2016. Patent Damages Law and Practice, 2016-2017 ed., Thomson Reuters.

Stern, Richard H. 2015. "What Are Reasonable and Non-Discriminatory Terms for Licensing a Standard-Essential Patent?,” European Intellectual Property Review 37: 549-57.

Stout, Lynn A. 2011. Cultivating Conscience: How Good Laws Make Good People, Princeton N.J.: Princeton University Press.

Swanson, Daniel G. \& William J. Baumol. 2005. "Reasonable and Nondiscriminatory (RAND) Royalties, Standards Selection, and Control of Market Power,” Antitrust Law Journal 73: 1-58. 
Taylor, David O. 2014. “Using Reasonable Royalties to Value Patented Technology,” Georgia Law Review 49(1): 79-162.

Teece, David J. \& Edward F. Sherry. 2016. “'Smallest Saleable Patent Practicing Unit’ Doctrine: An Economic and Public Policy Analysis,” Working Paper Series No.11: 1-33. http://innovationarchives.berkeley.edu/businessinnovation/documents/Tusher-Center-Working-Paper-11.pdf

Verma, Rohit, Gerhard Plaschka \& Jordan J. Louviere. 2002. “Understanding Customer Choices: A Key to Successful Management of Hospitality Services,” Cornell Hotel \& Restaurant Administration Quarterly 43(6): 15-24.

Ward, Annesley Merele. 2017. "Is German SEP litigation set to increase with the "confidentiality club decision" of the Higher Regional Court of Düsseldorf?,” The IPKat, Feb. 7, 2017. http://ipkitten.blogspot.com/2017/02/german-court-prowls-into-realm-of.html

Weinstein, Roy, Ken Romig \& Frank Stabile. 2013. “Taming Complex Intellectual Property Compensation Problems,” Federal Circuit Bar Journal 22(3): 547-61.

Yamaguchi, Kazuhiro. 2016. “Japanese Patent Litigation and Its Related Statistics--Current Environment and Future Agenda,” A.I.P.P.I.—Japan 41: 128-42. 
Yang, Zelin. 2014. “Damaging Royalties: An Overview of Reasonable Royalty Damages,” Berkeley Technology Law Journal 29: 647-78. 